\title{
A COMMENTARY ON THE RIGHT TO AN EFFECTIVE REMEDY IN THE CASE LAW OF THE CJEU
}

\section{HERWIG CH HOFMANN ${ }^{1}$}

1. Constitutional Context of the Right to an Effective Judicial Remedy .......................................... 3

a. The Minimum Level of Protection Defined by the ECHR ….................................................. 5

b. The Right to an Effective Remedy as an Essential Requirement of the Rule of Law.................. 6

c. Procedural and Organizational Autonomy of Member States ................................................. 6

2. Scope of Protection of the Right to an Effective Remedy …................................................... 8

a. Obligation to Protect 'Rights or Freedoms Guaranteed by the Law of the Union' ...................... 9

b. A Remedy Before a Court or Tribunal.................................................................................. 11

c. Remedies Sufficient to Ensure Effective Legal Protection........................................................13

3. The Right to An Effective Remedy and EU Institutions and Bodies...........................................16

4. The Right to an Effective Remedy and Member States ............................................................20

a. Specific Obligations Arising in the Context of Disputes between Individuals and National

Public Authorities - The 'vertical' Relation ..............................................................................20

(i) Specific Obligations in Disputes Regarding Individuals Challenging Public Acts ...............20

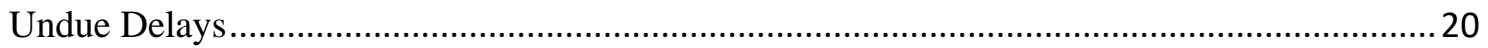

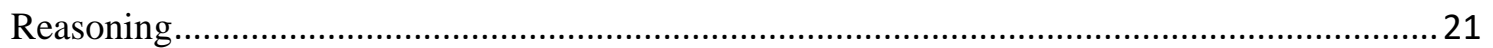

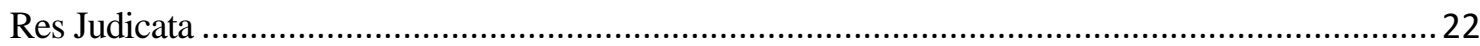

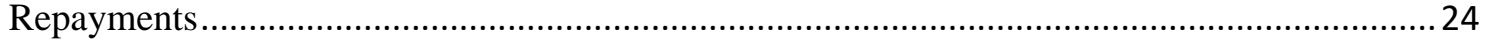

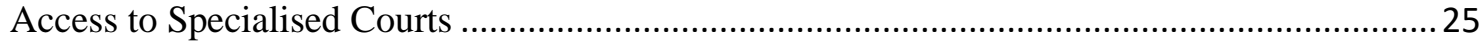

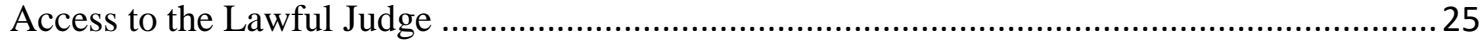

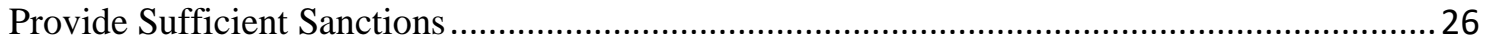

(ii) Effective Judicial Remedies Protected by Independent Agencies ..........................................26

(iii) Effective judicial remedies in composite procedures.......................................................2

b. Specific Obligations in Disputes between Individuals - The 'horizontal' Relation ....................32

(i) Indirect Horizontal Effect of the Right to Effective Remedies ........................................... 32

1 Professor of European and Transnational Public Law; University of Luxembourg-Faculty of Law, Economics and Finance-Robert Schuman Initiative for European Affairs. 
Provide sufficient sanctions for non-compliance.

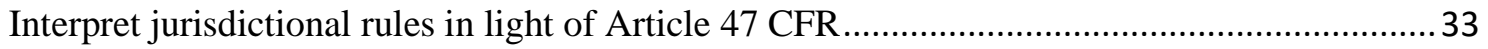

Conduct ex officio review of EU law by national courts and tribunals.....................................34

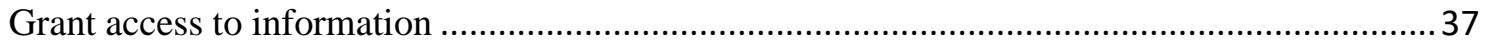

Policy specific case law regarding obligations under Article 47 CFR ......................................38

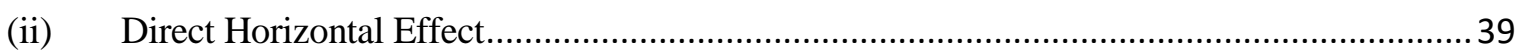

5. Limitations on the Right to an Effective Remedy Before a Court or Tribunal of the Member State 41

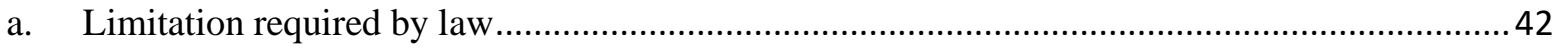

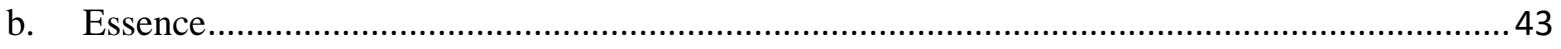

c. Proportionate limitations of the Right to an Effective Judicial Remedy...................................44

6. Access to Judicial Review versus the Question of Degree of Review........................................ 46

The right to an effective judicial remedy is an essential element of realising the rule of law. It is the fundamental right granting individuals the possibility to request independent review of compliance with the legal provisions. The genius of protecting as an individual fundamental right this structural notion of independent judicial review, has much contributed to the prominence and the protection of judicial accountability and effective enforcement of EU law. Yet, this critical commentary on the right to an effective remedy shows that the case law of the CJEU has predominantly aimed at ensuring Member State compliance with the right to an effective remedy. When it comes to reviewing EU law provisions against this right, the general considerations of ensuring effective judicial remedies are a lot less pressing, and accordingly, the CJEU has decided to be less stringent in its application of the right. Such case law of the CJEU has left gaps in protection. The commentary ends with the observations that additional problems for the enforcement of the right to an effective remedy arise from the often-composite nature of procedures, linking one or several Member State bodies with European institutions and bodies in one single procedure.

Accordingly, this critical commentary contains an analysis of the right to an effective remedy with respect to the Member States analyses the right to effective remedies in its constitutional context (a), before turning to the scope of protection offered under Article 47 CFR including the concept of the rights and freedoms, the notion of a court or tribunal and the discussion of remedies (b). The 
commentary then turns to the specific obligations in the 'vertical' relation of the right in disputes between individuals and public bodies (c) and the possibility of 'horizontal' effect of the right (d). The discussion then under (d) continues with considerations as to the CJEU's application of the right to an effective remedy a criterion for interpretation of EU law provisions. Given that no right is without limitations, and the relation between what has been understood as part of the right and what is understood as a limit with respect to Article 47 CFR is shifting (e). The last point discussed concerns differences between questions of access to justice as opposed to as the questions of the degree of judicial review.

\section{Constitutional Context of the Right to an Effective Judicial Remedy}

The right to an effective judicial remedy is deeply engrained in the constitutional order of the EU. The CJEU describes the origins and nature of this right as being a provision which is a general principle of EU law. It is linked to obligations in Article 19(1) TEU under which European courts, "shall ensure that in the interpretation and application of the Treaties the law is observed". Under the same article, Member States shall through their national courts provide "remedies sufficient to ensure effective legal protection in the fields covered by Union law." The CJEU has developed a formula outlining the notion of the right to effective remedies stating that

"The principle of the effective judicial protection of individuals' rights under EU law, referred to in the second subparagraph of Article 19(1) TEU, is a general principle of EU law stemming from the constitutional traditions common to the Member States, which has been enshrined in Articles 6 and 13 of the European Convention for the Protection of Human Rights and Fundamental Freedoms, [...], and which is now reaffirmed by Article 47 of the Charter."2

The right to an effective judicial remedy has thus been recognized as being deeply embedded in the EU's composite constitutional structure. It arises from obligations of Member States set out in Article 19(1) TEU, is protected as a general principle of EU law and is guaranteed by Article 47 CFR. According to the formula stated by the CJEU, the analysis of the right to an effective judicial

\footnotetext{
${ }^{2}$ C-64/16 Associação Sindical dos Juizes Portugueses (ASJP) ECLI:EU:C:2018:117, para 35 with references to C-432/05 Unibet [2007] ECR I-2271, para 37, and C-279/09 DEB, EU:C:2010:811, paras 29-33.
} 
remedy begins with the General Principle of EU law, which was established in Johnston, ${ }^{3}$ where the CJEU found that the "right to obtain an effective remedy in a competent court' ${ }^{4}$ is a General Principle of European law.

However, in its emanation under Article 47 CFR, Article 52(2) CFR requires consistent interpretation 'under the conditions and within the limits' defined by relevant Treaty provisions, including Article 19(1) TEU. Article 19 (1) TEU clarifying in effect that national judges are judges of Union law, is also a specification of the general obligation under the principle of sincere cooperation (Article 4(3) TEU) obliging Member States to 'take any appropriate measure, general or particular, to ensure fulfilment of the obligations arising' from EU law. The Court of Justice has repeatedly held that the principle of sincere cooperation includes the obligation of judicial enforcement of EU law before national Courts. ${ }^{5}$ The other side of the obligation of the Member States under Articles 4(3) and 19 TEU and the obligation of the CJEU to ensure that 'the law is observed' is the individual right to an effective judicial review.

This parallelism between rights and obligations does, however, not exclude that there is not perfect alignment. Member State obligations arising from Article 19 (1) TEU, which speaks of the "fields covered" by EU law, may require a broader reading than the notion of 'scope' or 'implementation' of EU law which defines the scope of application of EU general principles of law to Member States or under Article $51 \mathrm{CFR}$, defining the scope of application of the Charter including Article 47 CFR. The CJEU explained in ASJP, that "as regards the material scope of the second subparagraph of Article 19(1) TEU, that provision relates to "the fields covered by Union law", irrespective of

\footnotetext{
${ }^{3}$ Case 222/84 Johnston [1986] ECR 1651, para 19. For a broader background see Herwig C.H. Hofmann, Gerard C. Rowe, Alexander H. Türk, Administrative Law and Policy of the European Union, Oxford University Press (Oxford 2011), pp 139142 and 691-698.

${ }^{4}$ Case 222/84 Johnston [1986] ECR 1651, para 19. For a broader background see Herwig C.H. Hofmann, Gerard C. Rowe, Alexander H. Türk, Administrative Law and Policy of the European Union, Oxford University Press (Oxford 2011), pp 139142 and 691-698.

${ }^{5}$ See to the relation between the principle of sincere cooperation and the right to an effective judicial remedy e.g.: Case 33/76 Rewe [1976] ECR 1989, para 5; Case 45/76 Comet [1976] ECR 2043, para 12; Case 106/77 Simmenthal [1978] ECR 629, paras 21 and 22; C-213/89 Factortame and Others [1990] ECR I-2433, para 19; C-312/93 Peterbroeck [1995] ECR I4599, para 12; C-432/05 Unibet [2007] ECR I-2271, para 38: 'Under the principle of cooperation laid down in Article 10 EC [now Article 4(3) TEU], it is for the Member States to ensure judicial protection of an individual's rights under Community law'. The Court regularly recites the formulation according to which it is settled case-law that in the absence of Community rules governing the matter it is for the domestic legal system of each Member State to designate the courts and tribunals having jurisdiction and to lay down the detailed procedural rules governing actions for safeguarding rights which individuals derive from Community law, provided, however, that such rules are not less favourable than those governing similar domestic actions (the principle of equivalence) and do not render virtually impossible or excessively difficult the exercise of rights conferred by Community law (the principle of effectiveness).' See: C-63/01 Evans [2003] ECR I-14447, para 45 with reference also to C-120/97 Upjobn [1999] ECR I-223, para 32.
} 
whether the Member States are implementing Union law, within the meaning of Article 51(1) of the Charter". ${ }^{6}$ Therefore, given that the EU "is a union based on the rule of law in which individual parties have the right to challenge before the courts the legality of any decision or other national measure relating to the application to them of an EU act", ${ }^{7}$ the scope of obligations arising from Article 19(1) TEU may, arguably, in certain circumstances be broader than the notion of scope or of implementing EU law as developed by the CJEU. ${ }^{8}$

\section{a. The Minimum Level of Protection Defined by the ECHR}

The right to an effective judicial remedy under Article 52(3) of the Charter needs to be interpreted to at least the same level as relevant rights under the Convention as interpreted by the European Court of Human Rights. In fact, Union Courts, ever since recognising the right to an effective judicial remedy as general principle of EU law, have referred to its origins inter alia from Articles 6 and 13 of the ECHR. ${ }^{9}$ In the case law of the European Court of Human Rights, Article 6 is regarded as Lex specialis to Article 13 ECHR in that the requirements of Article 13 are 'absorbed by more stringent requirements of Article 6' ECHR. ${ }^{10}$ The effect of Article 13 ECHR is 'to require the provision of a domestic remedy to deal with ... an "arguable complaint" under the Convention and to grant appropriate relief.' ${ }^{11}$ The convention rights as minimum level of protection intend to allow Article 47 CFR and the General Principle of the right to an effective remedy under EU law offer protection which goes beyond this minimum standard in two ways: Frist, the Charter grants respect of rights before European and national courts and tribunals whereas the convention only addresses 'domestic' remedies before national courts. Second, as will be discussed in the following paragraphs more in detail, the convention is limited to the notion of the protection of rights as they arise from the convention whereas the right to an effective judicial remedy under EU law protects

\footnotetext{
${ }^{6}$ C-64/16 Associação Sindical dos Juizes Portugueses (ASJP) ECLI:EU:C:2018:117 para 29

${ }^{7}$ C-64/16 Associação Sindical dos Juizes Portugueses (ASJP) ECLI:EU:C:2018:117 para 31 with reference to C-583/11 P Inuit EU:C:2013:625, paras 91, 94 and the case-law cited.

${ }^{8}$ See e.g. C-562/12 Liivimaa Lihaveis MTÜ v Seirekomitee ECLI:EU:C:2014:2229, para 62: "In accordance with the settled case-law of the Court, the concept of 'implementing Union law' ... requires a certain degree of connection above and beyond the matters covered being closely related or one of those matters having an indirect impact on the other." See also: C-299/95 Kremrow EU:C:1997:254 para 16.

${ }^{9}$ M. Poelemans, La sanction dans l'ordre juridique communautaire Bruylant (Bruxelles, 2004), 621. See e.g.: Case 222/84 Johnston [1986] ECR 1651, paras 18 and 19; Case 222/86 Heylens and Others [1987] ECR 4097, para 14; C-424/99 Commission v Austria [2001] ECR I-9285, para 45; C-50/00 P Unión de Pequeños Agricultores v Council [2002] ECR I-6677, para 39; C467/01 Eribrand [2003] ECR I-6471, para 61; Case 12/08 Mono Car Styling [2009] ECR I-6653, para 47; Joined Cases C317/08 to C-320/08 Alassini [2010] ECR I-2213, para 61.

10 See e.g. Application 31556/03 Efendiyeva v Azerbaijan \59, ECHR 2007; 31720/02 Titarenko v Ukraine \80, ECHR 2012.

11 Application 63235/00 Vilho Eskelinen and Others v Finland [GC] \$80, ECHR 2007.
} 
with the words of Article 47(1) CFR any 'rights and freedoms guaranteed by the law of the Union'. Irrespective of these differences, in all cases where ECHR law is applicable and protects individuals, the right to an effective judicial remedy must at least offer the level of protection which Articles 6 and 13 ECHR would have guaranteed.

b. The Right to an Effective Remedy as an Essential Requirement of the Rule of Law Second, the right to an effective remedy is an essential requirement of ensuring the rule of law (Article 2 TEU) within the Union. ${ }^{12}$ The CJEU has summarised this in ASJP by stating that the "European Union is a union based on the rule of law in which individual parties have the right to challenge before the courts the legality of any decision or other national measure relating to the application to them of an EU act". ${ }^{13}$ Article 19 TEU, in this context "gives concrete expression to the value of the rule of law stated in Article 2 TEU, entrusts the responsibility for ensuring judicial review in the EU legal order not only to the Court of Justice but also to national courts and tribunals." 14 Therefore, as the CJEU now has repeatedly underlined, that the "very existence of effective judicial review designed to ensure compliance with EU law is of the essence of the rule of law." "15

\section{c. Procedural and Organizational Autonomy of Member States}

Although the 'form and extent' of remedies supplied by the Member States to enforce EU rights, as well as the procedural rules to make them operational are in principle within national competence, ${ }^{16}$ such autonomy needs to be exercised in the context of conditions set by EU law for all courts that may be called upon to adjudicate EU law. To the extent that a national court or tribunal may rule "on questions concerning the application or interpretation of EU law", it must

\footnotetext{
12 The recognition of which in the Union legal system famously going back to Case 294/84 Les Verts [1986] ECR 1339, paras 23, 24. The relation between the right to an effective judicial remedy and the rule of law is outlined in C-50/00 P Unión de Pequeños Agricultores v Council [2002] ECR I-6677, paras 38, 39.

${ }^{13}$ C-64/16 Associação Sindical dos Juízes Portugueses (ASJP) ECLI:EU:C:2018:117 para 31; C-583/11 P Inuit Tapiriit Kanatami and Others v Parliament and Council, EU:C:2013:625, paras 91 and 94.

${ }^{14}$ C-64/16 Associação Sindical dos Juizes Portugueses (ASJP) ECLI:EU:C:2018:117 para 32 with further references.

15 C-216/18 PPU LM ECLI:EU:C:2018:586 para 51; C-64/16 Associação Sindical dos Juízes Portugueses (ASJP) ECLI:EU:C:2018:117 para 36 with further references.

16 This is known as the principle of national procedural autonomy. It would appear that under the principle of sincere cooperation Member States are under obligation to ensure that its national procedural provisions enforce EU law and in doing so enjoy a margin of discretion - the limits of which also circumscribe the degree of the national procedural autonomy. See also D-U. Galetta, Procedural Autonomy of EU Member States: Paradise Lost?, Springer (Heidelberg 2010) with further references.
} 
be ensured that those courts meet "the requirements essential to effective judicial protection, in accordance with the second subparagraph of Article 19(1) TEU". ${ }^{17}$ This is inter alia a reason why national competencies were initially interpreted in the light of the obligations under the sincere cooperation principle before the more specific Articles 47 CFR and 19 TEU were included in the Treaties. Accordingly, much of the case law on the right to effective remedies concerns questions of access to national courts and the remedies available before them.

The notion of autonomy is a concept developed in the context of Article 4 TEU within which the obligation of sincere cooperation (Article 4(3) TEU) obliges Member States to offer remedies subject to the principles of equivalence and effectiveness. In fact, the CJEU has held that the "requirements stemming from the principles of equivalence and effectiveness apply both to the designation of the courts and tribunals having jurisdiction to hear and determine actions based on European Union law and to the definition of the procedural rules governing such actions." 18

Under the principle of equivalence, in the absence of applicable EU law, Member States must grant “the detailed rules governing actions for safeguarding an individual's rights under European Union law must be no less favourable than those governing similar domestic actions" - thus grant at least equivalent protection for violation of EU law to that available against breach of national law. ${ }^{19} \mathrm{~A}$ rule must "be applied without distinction, whether the infringement alleged is of Community law or national law". ${ }^{20}$ The similarity of a situation is subject to detailed case-by-case analysis. The Court looks at the purpose and effect of the national measure in question and checks whether "the purpose and cause of action are similar", ${ }^{21}$ or whether the case concerns "the same kind of charges or dues". 22

The notion of effectiveness will be discussed below, since the effectiveness requirement initially developed from the notion of sincere cooperation under Article 4(3) TEU (and its predecessors) is now more specifically enshrined in the notion of effective remedies under Article 47 CFR. In fact,

\footnotetext{
${ }_{17}$ C-64/16 Associação Sindical dos Juíres Portugueses (ASJP) ECLI:EU:C:2018:117, para 40; LM (n 5), para 51.

${ }^{18}$ C-93/12 ET Agrokonsulting-04-Velko Stoyanov ECLI:EU:C:2013:432, para 37; C-320/08 Alassini and Others [2010] ECR I2213, para 49; C-286/06 Impact [2008] ECR I-2483, para 47; C-261/95 Palmisani [1997] ECR I-4025, para 27; C-453/99 Courage and Crehan [2001] ECR I-6279, para 29.

19 C-205-15/82 Deutsche Milchkontor [1983] ECR 2633, para 17; C-453/99 Courage and Crehan [2001] ECR I-6279, para 29; C-93/12 ET Agrokonsulting-04-Velko Stoyanov ECLI:EU:C:2013:432, paras 35, 36 with further references.

20 C-231/96 Edis [1998] ECR I-4951, para 36; Joined Cases 66/79, 127/79 and 128/79 Salumi [1980] ECR 1237 , para 21.

21 C-326/96 Levez [1998] ECR I-7835, para 41.

22 C-231/96 Edis [1998] ECR I-4951, para 36; Joined Cases 66/79, 127/79 and 128/79 Salumi [1980] ECR 1237, para 21. For a detailed commentary on the principle of equivalence see section D.IV.
} 
given its status as accessory 'meta right' of protection, the right to an effective remedy under Article 47 CFR is one of the rights of the Charter most cited fundamental in the case law of the CJEU. ${ }^{23}$ It is invoked and adjudicated in the context of almost any 'field covered by EU law' as the formulation of Article 19(1) TEU aptly describes its scope of application. ${ }^{24}$ The origin of this understanding of the right in fact lies in the specific historic link of the notion of effective judicial protection with the general notion of 'effectiveness', a sub-principle to the notion of sincere cooperation (Article 4(3) TEU).

\section{Scope of Protection of the Right to an Effective Remedy}

Originally developed as general principle of EU law by the CJEU in mid-eighties of the past century from case law specifying Member State obligations to sincere cooperation and the more general notion of effectiveness, ${ }^{25}$ the right to an effective judicial review has seen a particularly dynamic development of its scope of protection. This results from the fact that the individual right to an effective remedy is directly linked to ensuring compliance by Member States with basic constitutional provisions of EU law such as notions of primacy, direct effect, and principles enshrined in Article 2 TEU such as the rule of law. The particularly dynamic nature of the right to an effective remedy and the very diverse contexts in which it is invoked has an implication for the scope of protection. It results from the requirements of protecting rights and freedoms in the context of a growing and deepening Union.

The CJEU develops the notion of effective remedies with respect to questions in at least directions: First the 'rights and freedoms' which need to be afforded protection (i); second, what qualifies as protection by a court or tribunal of a Member State (ii), third, what makes for de jure and de facto 'effective' protection in the context of procedural and substantive safeguards (iii).

\footnotetext{
${ }^{23}$ Simona Demková, Herwig C.H. Hofmann, 'Pocedural Principles', in: Katja Ziegler (ed.) General Principles of EU Law, (OUP, Oxford 2019) (forthcoming).

${ }^{24}$ Simona Demková, Herwig C.H. Hofmann, 'Pocedural Principles', in: Katja Ziegler (ed.) General Principles of EU Law, (OUP, Oxford 2019) (forthcoming).

25 The Court of Justice has repeatedly found this right to be a fundamental right of individuals resulting from the common constitutional traditions of the Member States and recognised Articles 6 and 13 of the ECHR. The fundamental rights arising from this are thus also protected as General Principles of EU law under Article 6(3) TEU. See e.g.: Case 222/84 Johnston [1986] ECR 1651, paras 18 and 19; Case 222/86 Heylens and Others [1987] ECR 4097, para 14; C-424/99 Commission v Austria [2001] ECR I-9285, para 45; C-50/00 P Unión de Pequeños Agricultores v Council [2002] ECR I-6677, para 39; C-467/01 Eribrand [2003] ECR I-6471, para 61; C-432/05 Unibet [2007] ECR I-2271, para 37; Joined Cases C402/05 P and C-415/05 P Kadi and Al Barakaat [2008] ECR I-6351, para 335; Case 12/08 Mono Car Styling [2009] ECR I6653, para 47; Joined Cases C-317/08 to C-320/08 Alassini [2010] ECR I-2213, para 61.
} 


\section{a. Obligation to Protect 'Rights or Freedoms Guaranteed by the Law of the Union'}

As it evolved in the Union jurisprudence, the right to an effective remedy under Article 47 CFR entails broader protection than guaranteed under Articles 6 and 13 ECHR in that Article 47 CFR grants protection against violation of any right or freedom arising under EU law - not just 'fundamental rights' explicitly enshrined within the Charter or the Convention. This broad notion thus includes protection of rights arising from Treaty provisions and legislative as well as nonlegislative acts of the institutions and bodies of the EU. It equally includes rights arising from general principles of EU law such as rights to non-discrimination, for example where Member State law is in violation. ${ }^{26}$

The right to an effective judicial remedy is an accessory right, in that it requires another right arising from EU law to be protected before it will become operative. Article 47 of the Charter, however, is formulated in a slightly confusing manner in that Article 47 CFR requires 'violation' of a right whereas under Article 13 ECHR it is explicitly recognised that the existence of an 'arguable claim' of a violation of a convention right suffices to make a claim under Article 13 ECHR. ${ }^{27}$ This same common-sense standard is also to be applied to the interpretation of the unfortunate wording of Article 47 CFR.

The definition of "rights and freedoms guaranteed by the law of the Union" is an autonomous concept of EU law. Remedies need to be supplied to individuals suitable to ensure that where there is a right under Union law, there is a remedy to ensure its enforcement. ${ }^{28}$ Thus, importantly, the identification of what constitutes a right to be protected is a matter of EU law, is to be decided under criteria arising from EU law. That requires Member States to apply their procedural provisions to protect rights arising under EU law, even if under a purely national situation, the

\footnotetext{
${ }^{26}$ Such was for example the case in Dansk Industrie where the CJEU required that "where national courts are called on to give judgment in proceedings between individuals in which it is apparent that the national legislation at issue is contrary to EU law, it is for those courts to provide the legal protection which individuals derive from the provisions of EU law and to ensure that those provisions are fully effective." See: C-441/14 Dansk Industri ECLI:EU:C:2016:278 (Grand Chamber) paras 29 and 42 with reference to: "Pfeiffer and Others, C-397/01 to C-403/01, EU:C:2004:584, paragraph 111, and KücüKdeveci, C-555/07, EU:C:2010:21, paragraph 45.” See also Joined Cases C-569/16 and C-570/16 Bauer and Others ECLI:EU:C:2018:871.

27 Hofmann, Rowe and Türk, Administrative Law and Policy (n 77) 203-16; A Eser, 'Artikel 47' in J Meyer (ed) Charta der Grundrechte der Europäischen Union, 3rd edn (Baden-Baden, Nomos, 2011) 572 [4]. The leading case under the ECHR appears to be Silver and Others App nos 5947/72, 6205/73, 7052/75, 7061/75, 7107/75, 7113/75, 7136/75 (ECtHR, 1975) [113].

${ }^{28}$ See Pekka Aalto and others, 'Article 47 - Right to an Effective Remedy and to a Fair Trial', The EU Charter of Fundamental Rights: A Commentary (Hart Publishing 2014) 1214; W van Gerven, 'Of Rights, Remedies and Procedures' (2000) 37 Common Market Law Review 501, 511.
} 
legal system would not recognise such rights. For example, Member States are barred from applying approaches under national law that require criteria for the recognition of a right in addition to those required under EU law - often simply requiring that an obligation to be sufficiently clear, precise and unconditional and an individual having an interest in compliance with that. One example is Danske Slagterier, where the CJEU found that where a directive prohibits the Member States from preventing importation of properly inspected meat, this provision must be seen as granting "individuals the right to market in another Member State fresh meat that complies with the Community requirements" and thus obliging the Member State to afford the individual protection under the right to an effective remedy within the Member State. ${ }^{29}$ Equally, Olainfarm ${ }^{30}$ concerned the question whether a particular article of an EU directive on admission of medicines to the single market contained an individual right which would give rise to an effective judicial remedy. ${ }^{31}$ In searching for a right under the EU legal system, the CJEU focussed on the nature of the obligation imposed by the directive on one party instead of looking at whether the EU legislature had explicitly intended to create a subjective right in the directive. The CJEU held that where a directive imposes an unconditional and sufficiently precise obligation on a Member State, it is then for EU law to identify whether such directive "confers a concomitant right" on individuals, ${ }^{32}$ which is to be protected by the Member States courts, even if under their national procedural law the Member State would not have recognised the protection of such 'concomitant right' in a purely national context. ${ }^{33}$ The CJEU took the same approach in Bund für Umwelt und Naturschut $^{34}$ - a preliminary reference to the CJEU for interpretation of a directive on environmental impact assessments and the Habitats directive. The German legal provisions implementing the directives had been interpreted by German courts as excluding standing for environmental NGOs. The CJEU by contrast held that the provisions of the directive allowing standing in court for NGOs to defend the interests protected by the directives being "unconditional

${ }^{29}$ C-445/06 Danske Slagterier ECLI:EU:C:2009:178 para 24 explicitly refuting the Opinion of AG Trstenjak in C-445/06 Danske Slagterier EU:C:2008:464 arguing for an 'intentionalist' approach to identifying individual rights under EU law.

30 C-104/13 Olainfarm EU:C:2014:2316.

${ }^{31}$ C-104/13 Olainfarm EU:C:2014:2316 para 22.

32 C-104/13 Olainfarm EU:C:2014:2316 paras. 36-7, concerning the right to refuse access to information contained in the dossier used to register a medicinal product. See also C-115/09 Bund für Umwelt und Naturschutr, EU:C:2011:289 para 54.

${ }^{33}$ C-104/13 Olainfarm EU:C:2014:2316 para. 36-7. In that case it was the right to refuse access to information contained in the dossier used to register a medicinal product.

${ }^{34}$ Judgment of 12 May 2011, Bund für Umwelt und Naturschutz. Deutschland, Landesverband Nordrhein Westfalen, C-115/09, EU:C:2011:289. 
and sufficiently precise", ${ }^{35}$ NGOs may therefore rely on these provisions "even where (...) the rules relied on protect only the interests of the general public and not the interests of the individuals." ${ }^{\prime 6}$ Slightly more limiting, on the other hand, is the judgement in Gruber where the CJEU recognised that in the context of the principles of effectiveness and equivalence, Member States nonetheless "have a significant discretion to determine what constitutes 'sufficient interest' or "impairment of a right", under their national procedural rules for granting access to courts. ${ }^{37}$ However, the Court finds that this discretion can be limited by specific EU legislation. ${ }^{38}$

A very generally formulated 'reserve right' has been developed under the case law of the CJEU, specifically in relation to Article $47 \mathrm{CFR}$. According to this case law, any regulatory limitation of individual freedoms is protected as a 'right' in the context of Article 47 CFR. This was established by the CJEU in the development of a general defence right against public intrusions in the private sphere in Hoechst and confirmed in landmark rulings such as Roquette Frères, Minoan Lines and Berlioz. ${ }^{39}$ There, the CJEU linked the protection afforded under the right to an effective remedy to the general principle of EU law under which there is "protection against arbitrary or disproportionate intervention by public authorities in the sphere of the private activities of any natural or legal person." ${ }^{40}$ This grants a possibility to defend against any public intervention into the enjoyment of rights and thus amounts to a general defence right of individuals.

\section{b. A Remedy Before a Court or Tribunal}

The CJEU has drawn a link between substantive rights and the existence of a remedy in its early cases such as Johnston, where it identified the "right to obtain an effective remedy in a competent court" 41 as a general principle of European law. Effective judicial protection must be offered by

35 C-115/09 Bund für Umwelt und Naturschutz. EU:C:2011:289, para 54.

${ }^{36}$ C-115/09 Bund für Umwelt und Naturschutz EU:C:2011:289, para 59. See also Judgment of 16 April 2015, Gruber, C570/13, EU:C:2015:231, para 41, and Judgment of 15 October 2015, Commission v Germany, C-137/14, EU:C:2015:683, para 90-94. The application of the German Schutznorm could therefore not override the obligation to protect rights allocated under EU law. Similar in: C-664/15 Protect Natur EU:C:2017:987, paras 44, 46, 48.

${ }^{37}$ C-570/13 Gruber EU:C:2015:231, paras 37-39 with reference to C-115/09 Bund für Umwelt und Naturschutz. EU:C:2011:289, para 55; C-72/12 Gemeinde Altrip and Others EU:C:2013:712, para 50.

${ }^{38}$ In that case, citing Article 11(3) of Directive 2011/92 and the second paragraph of Article 9(2) of the Aarhus Convention.

${ }^{39}$ C-682/15 Berlioz Investment Fund S A ECLI:EU:C:2017:373, para 51; C-121/04 P Minoan Lines v Commission EU:C:2005:695, para 30 ; C-94/00, Roquette Frères EU:C:2002:603, para 27; Joined Cases 46/87 and 227/88 Hoechst v Commission EU:C:1989:337, para 19

40 C-682/15 Berlioz Investment Fund SA ECLI:EU:C:2017:373, para 51.

41 Case 222/84 Johnston [1986] ECR 1651, para 19. For a broader background see HCH Hofmann, GC Rowe and AH 
courts and tribunals recognised as such by EU law. In reality, it is primarily the national courts which are required to apply EU law as first-order 'Union judges' in the context of Article 19(1) TEU. The notion of a competent court includes the CJEU where a reference must be undertaken. The CJEU has reconfirmed this in Commission v France concerning the wrongful refusal of the French Conseil d'Etat to submit a question on the interpretation of EU law as court of last instance under Article 267 TFEU. ${ }^{42}$

Union law has set up a series of criteria for the recognition of a court or tribunal, most of which are linked to criteria of independence and impartiality. ${ }^{43}$ Initially, the relevant definition of a national court or tribunal had been developed by analogy with the case law identifying which bodies may make a preliminary reference under Article 267 TFEU. ${ }^{44}$ In more recent case law such as $L M$, further criteria have been specifically developed based on requirements of the rule of law (Article 2 TEU), now including the requirement of independence with internal aspects linked to judicial independence and external aspects linked to the notion of autonomy vis-à-vis other branches of powers.

The 'internal' dimension of the independence and impartiality of the tribunal is assessed by considering factors such as whether the body is established by law, whether it is set-up ad-hoc or permanently and whether its jurisdiction is compulsory. Further criteria refer to whether its procedure is inter partes. ${ }^{45}$

The 'external' dimension protects the autonomy of courts in that they should not be "subject to any hierarchical constraint or subordinated to any other body" and be "protected against external interventions or pressure liable to impair the independent judgment of its members and to influence

\footnotetext{
Türk, Administrative Law and Policy of the European Union, (Oxford, Oxford University Press, 2011) 139-42, 691-98.

${ }^{42}$ C-416/17 Commission v France (Précompte mobilier) ECLI:EU:C:2018:811, para 113. In this case, the CJEU implicitly endorsed the concept known in German and Austrian law as the right to a specific judge, predetermined by the law, as an essential element of the rights to judicial remedies under the rule of law. This concept is known as "gesetzlicher Richter".

43 Case 14/86 Pretore di Salò [1987] ECR 2545 [7]; Case 338/85 Pardini [1988] ECR 2041 [9]. For a full analysis of the meaning of 'court or tribunal' in EU law, see section D.VII.

44 C-506/04 Wilson [2006] ECR I-8613, para 48 with reference (by analogy) to Joined Cases C-238/99 P, C-244-245/99P, C-250/99P, C-252/99P, C-254/99P Limburgse Vinyl Maatschappij and Others [2002] ECR I-8375 [180][205], [223], [234].

${ }^{45}$ For the development of criteria see, Case 338/85 Pardini, EU:C:1988:194, para 9; Case 14/86 Pretore di Salò EU:C:1987:275, para 7; C-54/96 Dorsch Consult, EU:C:1997:413, para 23; Joined Cases C-110/98 to C-147/98 Gabalfrisa and Others, EU:C:2000:145, para 33; C-17/00 De Coster, EU:C:2001:651, para 10; C-506/04 Wilson [2006] ECR I-8613, para 48 ; C-64/16 ASJP (n 1), paras 33-37; C-216/18 PPU LM ECLI:EU:C:2018:586, para 51 - with further references.
} 
their decisions". ${ }^{46}$ This presupposes that judges have certain guarantees against removal from office, ${ }^{47}$ and receive adequate levels of remuneration. ${ }^{48}$ EU law requires Member States to ensure that its courts enjoy procedural guarantees for "objectivity and the absence of any interest in the outcome of the proceedings apart from the strict application of the rule of law." 49 Member States must especially set rules on "the composition of the body, the appointment, length of service and grounds for abstention, rejection and dismissal of its members." ${ }^{\circ 0}$ Any disciplinary regime concerning judges must guarantee that it cannot be used as "a system of political control of the content of judicial decisions." ${ }^{51}$ A violation of these Member State obligations under Article 19(1) TEU can result in a violation of the individual right to an effective remedy.

\section{c. Remedies Sufficient to Ensure Effective Legal Protection}

The degree to which Member State courts are bound by the right to an effective judicial remedy is defined by the Court of Justice's jurisprudence on the compatibility with EU law of national procedural and substantive rules that have an actual or potential effect on the existence, degree and enforceability of remedies to enforce rights arising from EU law. ${ }^{52}$

The extent of the guarantee of "real and effective judicial protection" 53 was developed by the CJEU as a defence right against "any provision of a national legal system and any legislative, administrative or judicial practice which might impair the effectiveness" of Union law $^{54}$ in cases such as Van Colson and Factortame. The key obligation of Member States was not to "render virtually impossible or excessively difficult the exercise of rights conferred by Community law'. ${ }^{55}$ The questions whether a national procedural provisions renders the exercise of an individual's rights

\footnotetext{
${ }^{46}$ C-216/18 PPU LM ECLI :EU :C :2018 :586, para 63 ; C-64/16 Associação Sindical dos Juizes Portugueses (ASJP) ECLI:EU:C:2018:117, para 44.

${ }^{47}$ C-506/04 Wilson [2006] ECR I-8613, para 51; C-216/18 PPU LM ECLI:EU:C:2018:586, para 64.

${ }^{48}$ C-64/16 Associação Sindical dos Juizes Portugueses (ASJP) ECLI:EU:C:2018:117, para 45.

${ }^{49}$ C-506/04 Wilson [2006] ECR I-8613, para 52.

${ }^{50}$ C-216/18 PPU LM ECLI :EU :C :2018 :586, para 66 ; C-222/13 TDC, EU :C :2014 :2265, para 32.

${ }^{51} \mathrm{C}-216 / 18$ PPU $L M$ ECLI :EU :C :2018:586, para 67.

52 AG Trstenjak offered an extensive interpretation of this expression in her Opinion in C-411/10 N.S. [2011], paras 149177, also including infringements of the Geneva Convention and the ECHR.

53 Case 14/83 Van Colson [1984] ECR 1891, para 23.

${ }^{54}$ C-213/89 Factortame [1990] ECR I-2433, paras. 19, 20

55 See eg C-128/93 Fisscher [1994] ECR I-4583, para 37; C-261/95 Palmisani [1997] ECR I-4025, para 27; C-453/99 Courage and Crehan [2001] ECR I-6279, para 29; C-78/98 Preston and Others [2000] ECR I-3201, para 39; C-187/00 KutzBauer [2003] ECR I-2741, para 57; C-30/02 Recheio-Cash \& Carry [2004] ECR I-6051, paras 17, 18; C-212/04 Adeneler and Others [2006] ECR I-6057, para 95; Joined Cases C-231/06 to C-233/06 Jonkman and Others [2007] ECR I-5149, para 28.
} 
under EU law "impossible in practice or excessively difficult" must be assessed taking into consideration all relevant principles and arrangements of the national system concerned "such as the protection of rights of defence, the principle of legal certainty and the proper conduct of the proceedings." 56

CJEU case law has, however also held that Member States have a positive obligation to grant and ensure that their courts provide "direct and immediate protection" of rights arising from the Union legal order, ${ }^{57}$ and, in the context of Article 19(1) TEU, more generally to offer "effective legal protection in the fields covered by Union law". ${ }^{58}$ Under the notion of effectiveness, by analogy with Article 13 ECHR "must be 'effective' both in law and in practice." ${ }^{, 9}$ Real effectiveness thus covers matters of procedural and substantive law: It includes matters of admissibility of bringing cases and of the concept of standing, ${ }^{60}$ the existence of interim protection ${ }^{61}$ and (now explicitly recognised in Article 47 paragraph 2) the existence of legal aid and the conditions of its disbursement. ${ }^{62}$

The notion of effectiveness can entail positive obligations. Although the Court of Justice initially stated in Rewe that the right to effective judicial review "was not intended to create new remedies", 63 the concept has rapidly evolved due to the case law of the Court on the principle of effectiveness under which national courts are required to offer active protection of rights arising from Union law and are obliged to "guarantee real and effective judicial protection" 64 even in cases such as Factortame where a the court would grant interim relief, if it were not for a rule of national law, is obliged to set aside that rule. Anything which "might prevent, even temporarily, Community rules from having full force and effect" therefore must be held to be incompatible with Union law. ${ }^{65}$

Although the Court also took the opportunity in Inuit to reassert that in principle "neither the FEU Treaty nor Article 19 TEU intended to create new remedies before the national courts to ensure

\footnotetext{
${ }^{56}$ C-93/12 ET Agrokonsulting-04-Velko Stoyanov ECLI:EU:C:2013:432, para 48; C-63/08 Pontin [2009] ECR I-10467, para 47 with further references.

${ }^{57}$ Case 13/68 Salgoil [1968] ECR 453 at page 463.

${ }^{58}$ C-64/16 Associação Sindical dos Juizes Portugueses (ASJP) ECLI:EU:C:2018:117 ; Case 222/84 Johnston [1986] ECR 1651, para 18; Case 179/84 Bozzetti [1985] ECR 2301, para 17.

59 Kudla v Poland ECHR 2000-XI, para 157.

${ }^{60}$ C-104/13 Olainfarm ECLI :EU :C :2014 :2316 paras 35, 38; C-664/15 Protect Natur EU:C:2017:987, paras 44, 46, 48.

${ }^{61} \mathrm{C}-213 / 89$ Factortame [1990] ECR I-2433, paras. 19, 20.

${ }^{62} \mathrm{C}-279 / 09$ DEB ECLI :EU :C :2010 :811, paras 59-62.

63 Case 158/80 Rewe II [1981] ECR 1805, summary point 6.

${ }^{64}$ Case 14/83 Van Colson [1984] ECR 1891, para 23.

65 C-213/89 Factortame [1990] ECR I-2433, paras. 19, 20.
} 
the observance of European Union law other than those already laid down by national law", ${ }^{66}$ the CJEU in Inuit was equally at pains to recall that the right to an effective remedy can very well require, exceptionally, the Member State bodies to create new remedies, "if the structure of the domestic legal system concerned were such that there was no remedy making it possible, even indirectly, to ensure respect for the rights which individuals derive from European Union law, or ... of the sole means of access to a court was available to parties who were compelled to act unlawfully." 67 This means that a global assessment of the Member State legal system needs to be made by a national before the last resort measure of crafting a new remedy is taken. ${ }^{68}$

Compliance with the right to an effective remedy then depends both on whether the Member State offers procedural rules granting fair prospects for a case to be instituted and provides admissibility criteria allowing actual access to a court. An example is Liivimaa Lihaveis obliging a national court to hold an action brought against a decision by a national agency admissible, even if the national rules of procedure do not provide for this in such a case. ${ }^{69}$

Compliance with the right to an effective remedy also requires provision of a remedy which can address the violation of the right. ${ }^{70}$ Since Peterbroeck and Van Schijndel, these criteria have been combined into one standard formulation. The right to an effective judicial remedy means that

66 C-583/11 P Inuit Tapiriit Kanatami, para 103.

67 C-583/11 P Inuit Tapiriit Kanatami, para 104.

68 For a detailed analysis of the limits on the powers of Member State courts to craft new remedies see the Opinion of 14 March 2013 of Advocate General Jääskinen in C-509/11 OBB-Personenverkehr AG (Judgment of 26 September 2013), paras 68-78. At para 77 the Advocate General pointed out that, moreover, it is established that, when a Member State, in the exercise of its discretion "to designate the courts and tribunals having jurisdiction and to lay down the detailed procedural rules governing actions for safeguarding rights which individuals derive from Community law" has left room for argument of a compliance failure appertaining to the principle of effectiveness, the obligation imposed by EU law on national courts is merely "to interpret the domestic the jurisdictional rules in such a way that, wherever possible, they contribute to the attainment of the objective of ensuring effective judicial protection of an individual's rights under Community law"' (emphasis in original). See further C-268/06 Impact [2008] ECR I-2483, para 54, Joined C-444/09 and C-456/09 Gavieiro [2010] ECR I-14031, para 95, 96 and C-240/09 Lesoochranarske zoskupenie [2011] ECR I-1255, para 51. ${ }^{69}$ C-562/12 Liivimaa Lihaveis MTÜ v Seirekomitee EU:C:2014:2229, paras 60, 61.

70 See by comparison the approach to Art 13 ECHR in MSS v Belgium and Greece App no 30696/09 (ECtHR 2011) [289], [290]: "The "effectiveness" of a "remedy" within the meaning of Article 13 does not depend on the certainty of a favourable outcome for the applicant. Nor does the "authority" referred to in that provision necessarily have to be a judicial authority; but if it is not, its powers and the guarantees which it affords are relevant in determining whether the remedy before it is effective. Also, even if a single remedy does not by itself entirely satisfy the requirements of Article 13, the aggregate of remedies provided for under domestic law may do so. In order to be effective, the remedy required by Article 13 must be available in practice as well as in law, in particular in the sense that its exercise must not be unjustifiably hindered by the acts or omissions of the authorities of the respondent State' (with references to Gebremedhin [Gaberamadhien] v

France ECHR 2007-V [53] and Cakucu v Turkey ECHR 1999-IV [112]). Regarding the EU legal system, see: S. Alber, 'Recht auf einen wirksamen Rechtsbehelf und ein unparteiisches Gericht-Art 47' in P. Tettinger, K. Stern (eds), Kölner Gemeinschaftskommentar zur Europäischen Grundrechte-Charta (Munich, Verlag CH Beck, 2006) 734, para 34. 
Member State law must not render the application of Union law 'impossible or excessively difficult'. ${ }^{71}$ Whether that is the case must be analysed

"by reference to the role of that provision in the procedure, its progress and its special features, viewed as a whole, before the various national instances. In the light of that analysis the basic principles of the domestic judicial system, such as protection of the rights of the defence, the principle of legal certainty and the proper conduct of procedure, must, where appropriate, be taken into consideration." 72

The consequences of this analysis are best illustrated by the cases that have considered both procedural remedies in the sense of individual rights of access to a court as well as the substantive remedies available where a claim is successful. Both have been addressed in disputes in which individuals claim that rights arising from EU law have been violated by public authorities, either of the EU or the Member States (the 'vertical' relation), and in disputes between individuals (the 'horizontal' relation). It is to these developments to which the following discussion on specific developments and case law relating to these different situations will turn in the following.

\section{The Right to An Effective Remedy and EU Institutions and Bodies}

The protection of the right to an effective judicial remedy as General Principle of EU law and as a right under Article 47 CFR binds EU institutions and bodies (Article 51 CFR). For the general principle of EU law this was reconfirmed in e.g. no other case than Les Verts. ${ }^{73}$ In Kadi I, the CJEU states that,

"Courts of the EU must, in accordance with the powers conferred on them by the Treaties, ensure the review, in principle the full review, of the lawfulness of all Union acts in the light of the fundamental rights forming an integral part of the EU legal order."74

\footnotetext{
71 C-312/93 Peterbroeck [1995] ECR I-4599, para 14 and Joined Cases C-430 and 431/93 Van Schijndel [1995] ECR I-4705, para 19.

72 Joined Cases C-430 and 431/93 Van Schijndel [1995] ECR I-4705, para 19. More recently the Court has held that it is 'apparent from the Court's case law that situations in which the question arises as to whether a national procedural provision makes the exercise of rights conferred on individuals by the European Union legal order impossible or excessively difficult must be analysed by reference to the role of that provision in the procedure as a whole and to the progress and special features of the procedure before the various national bodies'. See C-249/11 Hristo Bykanov (Judgment of 4 October 2012), para 75.

73 Case 294/83 Les Verts [1986] ECR 1339, para 23.

${ }^{74}$ Joined Cases C-584/10P, C-593/10P and C-595/10P Commission and Council v Kadi (Kadi II) of 18 July 2013.
} 
In Rosneft $t^{75}$ the question arose whether there could be a preliminary reference on matters against which there is no direct recourse such as with respect to CFSP matters in view of Art 40 TEU. This question was applied to sanctions decided by the Council for which the CJEU has jurisdiction ex ratione materiae to rule on the validity of restrictive measures (Art 24(1), $40 \mathrm{TEU}$ and $2^{\text {nd }}$ para of Art. 275 TFEU). The CJEU held that judicial monitoring of these CFSP matters "falls within the scope of the general jurisdiction that Article 19 TEU" which "confers on the Court to ensure that in the interpretation and application of the Treaties the law is observed." ${ }^{\prime 76}$ The reason for this broad response was that "a reference for a preliminary ruling on the validity of a measure plays an essential part in ensuring effective judicial protection, particularly, where, as in the main proceedings, both the legality of the national implementing measures and the legality of the underlying decision adopted in the field of the CFSP itself are challenged within national legal proceedings." 77 This is in line with cases which have confirmed the Court's position that "the very existence of effective judicial review designed to ensure compliance with provisions of EU law is of the essence of the rule of law"78 and hence a broad interpretation of the powers of national courts to request a preliminary ruling to the CJEU was found to exist. The Court in Rosneft continues to state that "[w]hile admittedly Art 47 CFR cannot confer jurisdiction on the Court, where the Treaties exclude it," "the principle of effective judicial protection nonetheless implies that the exclusion of the Court's jurisdiction in the field of the CFSP should be interpreted strictly." This also arises from "the duty assigned to the Court under Article 19(1) TEU"79

Whether that means that the right to effective remedies is also to be used as criteria for the interpretation of Article 263 TFEU is less clear. According to the CJEU, despite this right being, as stated in Rosneft of the "essence for the rule of law", the CJEU has been very reluctant in the past to review its own practice of interpretation of conditions of the action of annulment under Article 263 TFEU against criteria of the right to an effective remedy. Unlike the plaintiffs in UPA, Jégo Quéré and Inuit had pleaded, for example, the CJEU granted no extension of the direct legal

\footnotetext{
${ }^{75}$ C-72/15 Rosneft of 28 March 2017.

${ }^{76}$ C-72/15 Rosneft of 28 March 2017, para 62.

77 C-72/15 Rosneft of 28 March 2017, para 71.

${ }^{78}$ C-562/13 Abdida, EU:C:2014:2453, para 45; C-362/14 Schrems I, EU:C:2015:650, para 95.

${ }^{79}$ C-72/15 Rosneft of 28 March 2017, paras 73-78 with reference by analogy to C-354/04 P, Gestoras Pro Amnistía, EU:C:2007:115, para 53; C-355/04 P Segi EU:C:2007:116, para 53; C-658/11 Parliament v Council, EU:C:2014:2025, para 70; C-439/13 P Elitaliana, EU:C:2015:753, para 42; C-455/14 P H v Council and Commission, EU:C:2016:569, para 40.
} 
remedies available to natural and legal persons against EU acts of legislative nature. ${ }^{80}$ Stating that the Treaties have "created a complete system of legal remedies", the CJEU held that Article 47 CFR and Article 19(1) TEU cannot be used as argument to broadly interpret Article 263 TFEU. Accordingly, the Court finds that the criteria under Article 263 TFEU should be interpreted rather narrowly putting much of the onus of ensuring effective judicial protection on Member State courts. The CJEU basis its argument on the consideration that "the Courts of the European Union may not, without exceeding their jurisdiction, interpret the conditions under which an individual may institute proceedings against a regulation in a way which has the effect of setting aside those conditions, expressly laid down in the Treaty, even in the light of the principle of effective judicial protection." ${ }^{81}$ This explanation is, however, only part of the story since not all conditions established in the Treaties are so obvious and clear, that they do not merit interpretation in the light of general principles of EU law. Therefore, the CJEU's statement in Inuit where the CJEU finds that Article 47 CFR "states in its explanations, to be taken into account under Art 6(3) TEU / 52(7) CFR that it is not intended to change the criteria of standing under the action for annulment", 82 adds to the understanding of the CJEU's reasoning and explains why the CJEU's reasoning as to Member State obligations under Article 47 CFR is distinctively different than the obligations Article 47 CFR imposes on Union courts. For example in Sky Österreich, the CJEU recalls that the right to an effective remedy can very well require, exceptionally, the Member State bodies to create new remedies in order to protect individual rights to an effective remedy. ${ }^{83}$ In cases concerning the interpretation of EU provisions in compliance with the general principle of the right to an effective remedy, the CJEU, on the other hand, does not consider that much of the its case law is based on a specific interpretation of the criteria contained in Article 263 TFEU, and that a broader, more accommodating approach is compatible with the wording and intentions of Article 263 TFEU. This approach must be revisited by the Court. Where there is room for interpretation, such interpretation needs to be conducted considering the general principles of EU law including that of effective protection.

\footnotetext{
${ }^{80}$ C-50/00 P UPA [2002] ECR I-6677, paras 37-40; C-263/02 P Jégo-Quéré [2004] ECR I-3425, paras 29, 30, 36; T-18/10 Inuit [2011] ECR II-nyr, paras 50-52.

${ }^{81}$ See: C-50/00 P UPA [2002] ECR I-6677, para 40; C-263/02 P Jégo-Quéré [2004] ECR I-3425, para 30; C-167/02 P Rothley [2004] ECR I-3149, para 46; C-461/03 Gaston Schul [2005] ECR I-10513, para 22.

${ }^{82}$ C-583/11 P Inuit para 97; C-283/11 Sky Österreich para 42.

${ }^{83} \mathrm{C}-283 / 11$ Sky Österreich para 42.
} 
This requirement is all the more important, since despite the CJEU's formulaic repetition of the Treaties having created a 'complete system' of forms of judicial review, gaps in protection can arise. AG Kokott in Inuit, ${ }^{84}$ pointed some of them out: In cases where individuals seek review of a legislative act with direct effect, which does not require further implementation, the CJEU has established in Jégo Quéré that it would be in violation of the right to an effective judicial review, if a natural person would first have to violate such law before invoking indirectly its illegality in defence against a penalty for violation of that act. AG Kokott suggested a remedy in her Opinion in Inuit consisting of a basic rule that where it is for Member States to enforce the law, Member States should provide for the right to a judicially reviewable reasoned decision with access to a preliminary reference procedure under 267 TFEU. If EU bodies implement EU law, they should be obliged to clarify the law by means of a binding decision subject to Art 263 TFEU. The latter point is important in the EU's reality. There are EU bodies such as the ECB which might pursue far reaching policies with mere factual acts or announcements which do not amount to final decisions. ${ }^{85}$ Other groupings such as the Eurogroup create far reaching and serious effects for individuals without formal decision-making power. Practically the most important instances of implementation without decision-making are the many preparatory acts which EU institutions and bodies adopt in composite procedures, where the input from an EU body is merely a supporting element of a final decision. ${ }^{86}$

One avenue in which the CJEU has, however, applied the right to an effective remedy to EU law has been in the context of damages for violation of Art 47 CFR. In a series of cases concerning the excessive length of procedures before the General Court (mostly related to Art. 101 and 102 TFEU) it has grants damages for violation of the right to an effective remedy in case of undue length of procedures. $^{87}$

\footnotetext{
${ }^{84}$ C-583/11 P Inuit [2013] ECR I-nyr, paras 115-122.

${ }^{85}$ See e.g. Case C-62/14 Gawweiler and Others v Deutscher Bundestag (OMT) of 16 June 2015, ECLI:EU:C:2015:400; C-493/17 Heinrich Weiss and Others ECLI:EU:C:2018:1000

${ }^{86}$ C-219/17 Berlusconi (Fininvest) ECLI:EU:C:2018:1023.

${ }^{87}$ C-50/12 P Kendrion v Commission (Grand Chamber); Case C-40/12 P Gascogne Sack v Commission (Grand Chamber); C58/12 P Groupe Gascogne v Commission (Grand Chamber). See also: C-414/12 P Bolloré v Commission of 8 May, 2014; C578/11 P Deltafina SpA v Commission, of 12 June 2014. For the reaction by the General Court: T-479/14, Kendrion NVv EU, Order of January 6, 2015.
} 


\section{The Right to an Effective Remedy and Member States}

\section{a. Specific Obligations Arising in the Context of Disputes between Individuals and}

National Public Authorities - The 'vertical' Relation

Specific obligations arising in the vertical disputes in which individuals claim rights and freedoms under EU against a public body arise both in the context of individuals challenging acts of public bodies (i) as well as, in specific situations, individuals requiring specific public authorities to fulfil their mandate to protect individuals (ii).

(i) Specific Obligations in Disputes Regarding Individuals Challenging Public Acts

The obligation of Member States may be imposed on their courts obliged to develop forms of judicial remedies in order to protect rights even where such protection did not pre-exist in national law. The CJEU has, in several high-profile cases, held that Member States and their courts are under the obligation to create remedies additional to those already existing under national procedural law, if it is necessary to guarantee the relation between rights and remedies under EU law. Examples can be found in Borelli, ${ }^{88}$ which concerned the protection of individuals in composite procedures with input from Union and Member State administrations into a final administrative decision; as well as Factortame, ${ }^{89}$ regarding the establishment of a system of interim relief to effectively protect a right under EU law.

However, as explained above, the more recent case law of the Court of Justice has placed emphasis on the caveat if necessary. It is only when the structure of the domestic legal system, taken as a whole, fails to provide an effective remedy, or the remedy available requires the law to be breached before access can be gained to a court, that national judges are bound under EU law to craft a new sanction. ${ }^{90}$

Undue Delays

88 C-97/91 Oleoficio Borelli v Commission EU:C:1992:491.

89 C-213/89 Factortame [1990] ECR I-2433. See recently on interim relief in the context of a discrete provision of environmental claims C-416/10 Jozef Krizan and Other (Judgment of 15 October 2013).

90 C-583/11 P Inuit Tapiriit Kanatami (n 68) [104]. For an example of a case in which the Court held that a Member State court was not required to issue the remedy requested, see C-91/08 Wall AG v Stadt Frankfurt am Main (Judgment of 13 April 2010). 
Undue delays in providing remedies due to lengthy procedures have been addressed by the European Court of Human Rights. It has been found that since remedies under Article 13 ECHR must be 'effective' both in law and in practice. An appeal can be rendered practically ineffective by the length of proceedings, ${ }^{91}$ and thus be in breach of Article 13 ECHR. ${ }^{92}$ Under Article 47 CFR, relevant jurisdictional rules may not cause individuals procedural problems in terms, inter alia, of the duration of proceedings, such as to render the exercise of the rights derived from European Union law excessively difficult. ${ }^{93}$ Individuals may seek damages for violation of rights under Article 47 of the Charter of Fundamental Rights in case of undue delays. ${ }^{94}$

\section{Reasoning}

The right to effective judicial review also contains procedural obligations which are incumbent on the legislative and executive branch of powers. The 'requirements of good administration and legal certainty and the principle of effective legal protection' are thereby linked. ${ }^{95}$ An example is the obligation on public bodies to reason their acts. This is positively formulated for EU institutions, bodies and agencies in Article 296 second paragraph TFEU and Article 41(2)(c) of the Charter, as well as in numerous provisions of secondary legislation. The European Courts have held that the obligation to reason acts also arises from the right to an effective judicial remedy. In that context, the obligation to give reasons is both an obligation of national bodies applying national law as well as one applicable to EU legal acts. ${ }^{96}$ The right to an effective judicial remedy 'requires statement

91 Application 63235/00 Vilho Eskelinen and Others v Finland [GC] \$80, ECHR 2007, para 29, with reference to Art 47 CFR; Kudla v Poland App no 30210/96 (ECtHR, 26 October 2000). For a detailed analysis of the question of delay in proceedings under EU and ECHR law, see section D.VIII.

92 See e.g. in this respect: Bottazzi v Italy ECHR 1999-V 22; Ci Mauro v Italy ECHR 1999-V 23; AP v Italy App no 35265/97 (ECtHR, 28 July 1999), para 18.

93 C-93/12 ET Agrokonsulting-04-Velko Stoyanov ECLI:EU:C:2013:432, and the Opinion of Advocate General Bot of 14 March 2013. On the scope of the duties of specialised tribunals to provide effective judicial protection, see C-268/06 Impact [2008] ECR I-2483.

${ }_{94}$ Accordingly, the General Court has with regard to the violation of the second paragraph of Article 47 CFR held that the duration of a procedure to adjudicate a case exceeding 20 months, could be considered to give rise to a claim for damages (T-577/14 Gascogne Sack Deutschland v EU ECLI:EU:T:2017:1, para 78).

95 C-362/09 P Atbinaïki Technikiv Commission [2010] ECR I-13275, para 70. For an example of a case in which an obstruce administrative practice was held to be in breach of the principle of effectiveness in the context of company law, see C-378/10 VALE Epitiesi kft (Judgment of 12 July 2012).

96 T-461/08 Evropaiki Dynamiki [2011] ECR II-06367, paras 118-124 which in a public procurement case held that in order to ensure the right to an effective remedy enshrined inter alia in Article $47 \mathrm{CFR}$, the contracting authority must comply with its duty to give reasons; in so far as the tendering procedure failed to satisfy those requirements, the 
of reasons in order to enable the entity concerned to exercise its right to bring an action', ${ }^{97}$ to 'decide, with full knowledge of the relevant facts', whether it is worth appealing to the courts ${ }^{98}$ and to enable the person concerned 'to defend his rights under the best possible circumstances' ${ }^{99}$

\section{Access to Documents}

Equally, the right of access to documents (now specifically protected under Article 42 and, with respect to one's own file also Article 41(2)b CFR) is a right directly linked to the notion of effective remedies in that access to files will in reality often be a necessary pre-condition for successful litigation in the context of enforcing "rights and freedoms guaranteed by the law of the Union." Further, the right to a fair hearing in a pre-litigation administrative phase has been linked to the requirements under the right to an effective protection, as have many other defence rights listed in Article 41 and 48 of the Charter. ${ }^{100}$

\section{Res Judicata}

The application of res judicata, a general principle of EU law, is not amongst the elements making an application impossible, and thus does not prejudice the right to an effective remedy before a tribunal for the purposes of Article 47 of the Charter of Fundamental Rights. ${ }^{101}$ The Court of Justice's case law has established that res judicata "extends only to the matters of fact and law actually or necessarily settled by the judicial decision in question". ${ }^{102}$ The "force of res judicata" the CJEU explains extends in principle "only to the grounds of a judgment which constitute the necessary support of its operative part". ${ }^{103}$ However, the judgement's ratio decidendi is also to be taken into account - especially in

applicant's right to an effective remedy was infringed.'

97 Joint Cases T-439/10 and T-440/10 Fulmen (Judgment of 21 March 2012), para 87; T-181/08 Tay Zav Council [2010] ECR II-1965, para 145; T-390/08 Bank Melli Iran v Council [2009] ECR II-3967, paras 35-37; Joined Cases C-402/05 P and C-415/05 P Kadi and Al Barakaat [2008] ECR I-6351, paras 335-353.

98 Joined Cases C-372/09 and C-373/09 Josep Peñarroja Fa [2011] ECR I-01785, para 63.

99 Case 222/86 Heylens and Others, paras 15 and 17. See recently on the link between the obligation to give reasons and effective judicial review C-430/10 Hristo Gaydarov [2011] ECR I-11637.

100 See especially cases C-249/13 Boudjlida, EU:C:2014:2431, paras 41 and 42 and C-166/13 Mukarubega, EU:C:2014:2336, paras 51 and 52 .

101 T-341/07 Sison v Council [2011] ECR II-07915, para 23; C-49/14 Finanmadrid EFC SA EU:C:2016:98, paras 45-46.

102 C-526/08 Commission v Luxembourg [2010] ECR I-6151, para 27 and the case law cited; C-529/09 Commission v Spain (Judgment of 24 January 2013), para 66; C-462/05 Commission v Portugal [2008] ECR I-4183, para 23.

103 Joined Cases C-539/10 P and C-550/10 P Stichting Al-Aqsa (Judgment of 15 November 2012), para 49 with further references. 
order to establish whether the facts and the points of law are the same. ${ }^{104}$ In a situation of res judicata of a national decision "EU law does not require a judicial body automatically to go back on a judgment having the authority of res judicata in order to take into account the interpretation of a relevant provision of EU law adopted by the Court after delivery of that judgment" 105 the CJEU explains in Târșia. ${ }^{106}$ None the less, in so far as the final judicial decision that was subsequently declared incompatible with EU law, was taken by a national court adjudicating at last instance, "by reason (inter alia) of the fact that an infringement, by such a decision, of rights deriving from EU law cannot thereafter normally be corrected, individuals cannot be deprived of the possibility of rendering the State liable in order to obtain legal protection of their rights."107

\section{Damages}

Amongst the practically most important substantive remedies capable of effectively enforcing rights under EU law is the obligation of Member States to make good damages which have arisen from their non-compliance with Union law. Such non-compliance can result from violation of primary law obligations which have direct effect, as well as from violation of secondary law obligations. In the landmark case of Francovich, ${ }^{108}$ the Court of Justice held that a Member State may be liable to pay damages in the case of faulty transposition of a directive if there are no possibilities for using the remedy of exceptionally granting the directive direct effect.

Even though the claim for damages arises from EU law, ${ }^{109}$ the procedures for obtaining damages are subject to national law which, under the principle of equivalence, may not provide for procedures for obtaining reparation that are 'less favourable than those relating to similar domestic claims'. ${ }^{110}$ In Brasserie du Pêcheur the Court of Justice applied this approach to breach by Member States of provisions of primary law contained in the EU Treaty. ${ }^{111}$ Liability of the Member States

\footnotetext{
104 C-456/11 Gothaer and Others v Samskip (Judgment of 15 November 2012), para 40 with reference to, inter alia, Joined Cases C-442/03 P and C-471/03 P P \& O European Ferries [2006] ECR I-4845, para 44; C-221/10 P Artegodan v Commission, ECLI:EU:C:2012:216, para 87.

105 C-69/14 Târşia EU:C:2015:662, para 38 with refrences to C-224/01 Köbler EU:C:2003:513, para 38 and C-213/13 Impresa Pizzarotti EU:C:2014:2067 para 60.

106 C-69/14 Târşia, EU:C:2015:662, paras 38, 40.

107 C-69/14 Târșia, EU:C:2015:662, para 40 with refrences to C-224/01 Köbler EU:C:2003:513, para 34 and C-173/03 Traghetti del Mediterraneo, C-173/03, EU:C:2006:391, para 31.

108 C-6/90 Francovich [1991] ECR I-5357.

109 C-6/90 Francovich [1991] ECR I-5357, paras 40-43.

110 C-6/90 Francovich [1991] ECR I-5357, para 43.

111 Joined Cases C-46 and 48/93 Brasserie du Pêcheur [1996] ECR I-1029. In parallel to the case law relating to Art 340
} 
was famously expanded in Köbler $^{112}$ and Traghetti $^{113}$ to make good damages due to violation of EU law by any of its authorities including the judiciary. ${ }^{114}$ National legislation limiting the liability of courts in these circumstances may be in violation of EU law because of the potential violation to the right to an effective remedy. ${ }^{115}$ Individuals will have such right to damages also in the context of violations of the rights under Article 47 CFR since, "individuals cannot be deprived of the possibility of rendering the state liable in order to obtain legal protection of their rights". ${ }^{116}$

\section{Repayments}

The right to an effective remedy before a tribunal also includes the obligation for Member State courts to order repayment of unduly levied sums by Member State in breach of EU law, ${ }^{117}$ or to order the administration to reopen a final administrative decision, ${ }^{118}$ especially if there is an equivalent possibility for violation under national law. ${ }^{119}$ In the context of enforcement of EU environmental law, Article 47 CFR includes a right for costs not to be prohibitively expensive, ${ }^{120}$

\footnotetext{
TFEU (eg Case 5/7 Zuckerfabrik Schöppenstedt [1971] ECR 975) the Courts require a 'sufficiently serious' breach of the rule of law which confers rights on individuals. The Court of justice might have applied an 'inverse' principle of equivalence in that the Member States would be held liable under EU law under the same conditions as the Union institutions and bodies.

112 C-224/01 Köbler [2003] ECR I-1023, para 31-36 and 53-55.

113 C-173/03 Traghetti [2006] ECR I-5177.

114 Ibid [43]: although liability, under these cases, is incurred 'only in exceptional cases where the national court adjudicating at last instance has manifestly infringed' the law, such manifest infringement is presumed where the 'decision involved is made in manifest disregard of the case-law of the Court on the subject.'

115 Ibid [37]-[45]. It was held that 'although it remains possible for national law to define the criteria relating to the nature or degree of the infringement which must be met before State liability can be incurred for an infringement of Community law', 'under no circumstances may such criteria impose requirements stricter than that of a manifest infringement of the applicable law, as set out in paragraphs 53 to 56 of the Köbler judgment.' See also on the preclusion of national concepts of fault, and the interaction of the principles of effectiveness and non-discrimination with state liability rules C-429/09 Gunter Fuß [2010] ECR I-12167. For further discussion of damages under Art 47 of the EU Charter, see section D.V.

116 C-69/14 Târşia EU:C:2015:662 [Grand Chamber], para. 40.

117 E.g. C-309/06 Marks \& Spencer plc [2008] ECR I-2283, paras 41-44; C-398/09 Lady and Kid [2011] ECR I-7375. See with further discussion: A Ward, Judicial Review and the Rights of Private Parties in EU Law, $2^{\text {nd }}$ edn (Oxford, Oxford University Press, 2007), 127-39.

118 C-249/11 Hristo Bykanov Judgment of 4 October 2012.

119 C-453/00 Kübne \& Heitr. [2004] ECR I-837, paras 23-27.

120 C-260/11 The Queen on the Application of David Edwards (Judgment of 11 April 2013) [33]. See also the Opinion of Advocate General Kokott of 18 October 2012 in the same case, in which the Advocate General observed at para 39 that 'legal protection under the Aarhus Convention [on access to justice in environmental matters] goes further than effective legal protection under Article 47 of the Charter of Fundamental Rights'. See further on effective judicial review in the context of EU environmental law C-416/10 Jozef Krizan and Others (Judgment of 15 January 2013) and the Opinion of Advocate General Kokott of 19 April 2012, and C-201/02 The Queen on the Application of Delena Wells [2004] ECR I-723 (environmental impact assessment).
} 
although, in the domain of criminal law, it does not guarantee to the victim of a criminal offence a right to require criminal proceedings to be brought against a third party in order to secure his or her conviction. ${ }^{121}$ In the field of public procurement, however, it has been accepted that the principles of equivalence and effectiveness do not preclude that a Member State charges multiple court fees to an individual who brings several parallel actions concerning the same award of a public contract. ${ }^{122}$

\section{Access to Specialised Courts}

There is no right under EU law to an effective remedy entail access to a number of levels of jurisdiction, ${ }^{123}$ final decisions on the implementation by Member State bodies of EU law, however, must be capable of being subject to thorough review by the national courts. ${ }^{124}$ The rights protected by Article 47 CFR necessarily preclude the designation, by Member States, of specialised tribunals to adjudicate over discrete areas of EU law.

However, Member States are barred from removing whole areas of law from its courts and tribunals in violation of Article 19(1) TEU and, implicitly, removing whole areas of law from the protection offered under the right to an effective judicial remedy by Member State and EU courts. In Achmea, the CJEU held that arbitration proceedings in which "Member States agree to remove from the jurisdiction of their own courts, and hence from the system of judicial remedies which the second subparagraph of Article 19(1) TEU requires them to establish in the fields covered by EU law" are illegal under EU law. Member States are thus barred from removing disputes which may concern the application or interpretation of EU law from courts provided for under Article 19(1) TEU. ${ }^{125}$

Access to the Lawful Judge

121 C-507/10 X and Y (Judgment of 21 December 2011), para 43.

122 C-61/14 Orizzonte Salute EU:C:2015:655, para. 79.

123 C-69/10 Dioufv Ministre du Travail, de l'Emploi et de l'Immigration ECLI:EU:C:2011:524, para 69. See also, in the context of the European arrest warrant, C-168/13 PPU Jeremy F v Premier minister (Judgment of 30 May 2013), para 44.

124 C-69/10 Diouf v Ministre du Travail, de l'Emploi et de l'Immigration ECLI:EU:C:2011:524, para 56; C-506/04 Wilson [2006] ECR I-8613, para 62.

125 C-284/16 Achmea ECLI:EU:C:2018:158 (Grand Chamber), para 55. The fact that Member States remove from their courts disputes concerning EU law distinguishes these specific arbitration agreements often contained in Bilateral Investment Agreements from ordinary commercial arbitration based on contractual freedom of the contracting parties, discussed below. 
Several Member States legal systems have created an additional obligation to ensure compliance with the right to an effective remedy, which has been referred to in the CJEU case law as the notion of the 'lawful judge', 126 'natural forum' ${ }^{\text {'27 }}$ or 'statutory judge'. ${ }^{128}$ Under this case law, developed for instance by the German, Czech and Austrian Constitutional Courts, individuals have a right that questions of interpretation or validity of EU law be referred to the CJEU under the preliminary reference procedure in order to ensure that the 'lawful judge' (gesetzlicher Richter) decide about the case in a proper forum. ${ }^{129}$

\section{Provide Sufficient Sanctions}

Member States must provide sanctions for violation of rights under EU law which are sufficient to make the sanctions provided "effective, proportionate and dissuasive." 130 They must be "sufficiently effective and a sufficient deterrent to ensure that" EU provisions "are fully effective" 131 and must be capable of being applied in order duly to punish that abuse and nullify the consequences of the breach of EU law. This is irrespective of whether the breach is caused by a Member State or whether the breach is reviewed in a dispute between individuals (the 'horizontal' situation). ${ }^{132}$ Therefore, Member State law must provide for sufficient sanctions also for breaches of obligations under EU law, as was established by the CJEU e.g. in the field of labour law in Santoro in which it was held that Member States must provide for an "effective measure to prevent and, where relevant, punish" the violation of EU law by public bodies. ${ }^{133}$

(ii) Effective Judicial Remedies Protected by Independent Agencies

\footnotetext{
126 T-199/11P Guido Strack ECLI:EU:T:2012:691, para 22.

127 T-93/95 Berard Laga ECLI:EU:T:1998:22, para 28.

128 Opinion of AG Geelhoed in C-25/03 Rinke ECLI:EU:C:2003:77, para 15.

${ }^{129}$ See e.g. German Constitutional Court BvR 1036/99, para 18, Czech Constitutional Court US 1009/08, para 21; Austrian Constitutional Court judgement 14.390/1995.

130 C-186/98 Nunes et de Matos [1999] ECR I-4883, paras 9-11 with reference to Case 68/88 Commission v Greece [1989] ECR 2965, para 23.

131 C-22/13, C-61/13 to C-63/13 and C-418/13 Mascolo and Others EU:C:2014:2401, paras 77, 79 with further references.

132 Regarding employment contracts C-53/04 Marrosu and Sardino EU:C:2006:517, para 48.

${ }_{133}$ Case C-494/16 Giuseppa Santoro, EU:C:2018:166, para 34 ; C-53/04 Marrosu and Sardino EU:C:2006:517, para 49.
} 
In order to ensure that the principle of effective judicial remedies is de facto complied with, the CJEU has been creative in deducting obligations from Article 47 CFR. For instance, it held that Member States must ensure that their independent supervisory authorities, which are tasked with protecting individual rights, to access to courts to request interpretation or to question the validity of acts of EU institutions and bodies. This type of declaratory action did not exist in many Member States but nonetheless, the CJEU has in Schrems I obliged Member States to introduce such option to ensure effective protection of individuals. In Schrems I the CJEU established this obligation in the context of the protection of personal data, a policy in which Article 8(3) CFR explicitly states that compliance with the rules on the protection of personal data "shall be subject to control by an independent authority." That authority, the CJEU held, must be able to engage in legal proceedings and it is thus "incumbent upon the national legislature to provide for legal remedies enabling the national supervisory authority concerned to put forward the objections which it considers well founded before the national courts in order for them, if they share its doubts as to the validity of the Commission decision, to make a reference for a preliminary ruling for the purpose of examination of the decision's validity." 134 The first reported preliminary reference of this kind was referred to the CJEU by the High Court of Ireland in a procedure initiated by the Irish Data Protection Commissioner. ${ }^{135}$

(iii) Effective judicial remedies in composite procedures

The right to an effective judicial remedy has been continuously adapted to EU law's changing modes of implementation. In the course of the past centuries, forms of joint multi-jurisdictional 'composite' procedures have become increasingly prevalent. In such procedures EU law provides for the cooperation in one procedure either of several Member State authorities or of a combination of Member State and EU authorities. The requirement to ensure effective judicial remedies in multi-jurisdictional composite procedures has been explicitly recognised by the CJEU in several cases, most explicitly in Berlusconi. ${ }^{136}$ However, since the procedures are regulated in a policy specific approach, in in lieu of a general administrative procedure regulation of the EU, ${ }^{137}$ the case

\footnotetext{
134 C-362/14 Schrems v DPC ECLI:EU:C:2015:650, paras 64, 65.

${ }_{135} \mathrm{C}-311 / 18$ DPC v Facebook and Schrems, pending.

136 C-219/17 Berlusconi (Fininvest) ECLI:EU:C:2018:1023, paras 44, 46.

137 See Article 298 TFEU.
} 
law has to date been evolving on a case-by-case basis non-exhaustively addressing individual constellations only. ${ }^{138}$ This case law recognises that in an increasing number of policy areas, implementing procedures for EU law involve actors from several jurisdictions, both national and European. The identification of the one or several jurisdictions which might have the competence to grant effective judicial review of acts adopted on the basis of such 'composite' procedures is not always easy. ${ }^{139}$ Input into a final decision may result from various jurisdictions, with each applying their national law. ${ }^{140}$ Review of such by the Court of the jurisdiction which adopted the final measure may not do justice to the requirements of effective judicial review of other jurisdictions involved, for example, in the promulgation of preparatory acts which preceded the measure. There is no right under EU law to effective judicial review of preparatory decisions. ${ }^{141}$ There is, therefore, in these multi-jurisdictional areas a potential mismatch between procedural integration of organisationally decentralised administrations across the Member States, on one hand, and a clear separation of judicial competencies among the same Member States, on the other. These gaps between dispersed decision-making powers and judicial review can be potentially detrimental to the application of the right to an effective judicial remedy. ${ }^{142}$ Four basic constellations can be identified:

Where the relevant procedures establish an EU institution or body as author of a final decision on the basis of non-binding input from national actors, it is for the CJEU to ensure effective judicial protection against the act and to review "any defects vitiating the preparatory acts or the proposals

\footnotetext{
138 Opinion of AG Sanches Bordona of 27 June 2018 in C-219/17 Berlusconi (Fininvest), paras 58-79 with a full review of the case law pre-dating Berlusconi and the literature on the matter.

139 Giacinto Della Cananea, G., 'I procedimenti amministrativi composti dell'Unione europea', in F. Bignami, F., S. Cassese, (eds.), Il procedimento amministrativo nel diritto europeo (Milano, Giuffrè, 2004); H.C.H. Hofmann, 'Composite decision making procedures in EU administrative law' in HCH Hofmann and A Türk (eds), Legal Challenges in EU Administrative Law (Cheltenham, Elgar Publishing, 2009) 136-67; H.-P. Nehl, 'Legal Protection in the Field of EU Funds' (2011) European State Aid Law Quarterly 629-52, 648; H.C.H. Hofmann and M. Tidghi, 'Rights and Remedies in Implementation of EU Policies by Multi-Jurisdictional Networks' (2014) 20 (1) European Public Law, 147-164; Mariolina Eliantonio 'Judicial Review in an Integrated Administration: The Case of "Composite Procedures" (2014) Review of European Administrative Law, 65-102; Brito Bastos 'Derivative illegality in European composite administrative procedures' (2018) Common Market Law Review, 101-134.

${ }^{140}$ For an excellent discussion of the issues, see Sergio Alonso de León, Composite Administrative Procedures in the EU, Iustel (Madrid, 2017). Examples for such multi-jurisdictional decision-making procedures arise in areas in which alert systems exist on the basis of which executive bodies from one Member State act implementing the warning of another such as in food safety or medicines. Alert systems also exist in the field of visa and immigration matters for example in the context of the Schengen Information System (SIS). Composite procedures also exist in the field of planning, in environmental law, emissions trading, transport and energy and many other fields.

141 C-69/10 Dioufv Ministre du Travail, de l'Emploi et de l'Immigration ECLI:EU:C:2011:524, paras 55, 56.

142 See with further descriptions: HCH Hofmann and M Tidghi, 'Rights and Remedies in Implementation of EU Policies by Multi-Jurisdictional Networks' (2014) 19 European Public Law, 147-164.
} 
of the national authorities that would be such as to affect the validity of that final decision." 143 The CJEU however, does not explain how it will be capable of undertaking judicial review of compliance of national procedural law in situations where no national court has initiated the preliminary reference procedure under Article 267 TFEU and has previously ruled on the legality of an act under national law. ${ }^{144}$ In an action for annulment under Article 263 TFEU the GC has no means of establishing the correct standard under national law. An 'inverse preliminary reference procedure' allowing references from an EU Court to a competent national Court, which could serve to such end, does not exist. ${ }^{145}$ On the other hand, review of the final EU act which has been established with input from other bodies can be ensured by means of a preliminary reference procedure. The CJEU has developed procedural tools to support national courts in this approach. For example, in Eurobolt the CJEU held that in the context of ensuring effective judicial remedies, ${ }^{146}$ national courts should have the means to assess whether decision-making on the European level considered all relevant information prior to decision making according to legal obligations - including information submitted by non-EU bodies. According to the CJEU in Eurobolt Articles 267 TFEU and the principle of sincere cooperation under Article 4(3) TEU require a national court to turn to the "EU institutions that have taken part in drawing up a piece of secondary EU legislation" requesting "specific information and evidence" on matters which a national court considers relevant for assessing the "validity of the EU act". By obtaining such information a national court may decide whether it has doubts about the validity of a final EU act so that it may either submit a preliminary reference to the CJEU for "the purpose of assessing the validity of that act" or, due to doubts about the validity being dispelled by the information received, avoid doing so. ${ }^{147}$

Where the procedures establish that the final decision is taken by a national authority, either because an EU institution or body has only given input into the decision-making procedure or because the EU institution is bound by a national act and has "only limited or no discretion" 148 it is for national courts to ensure effective judicial remedies of the act, "even if the national rules of

\footnotetext{
143 C-219/17 Berlusconi (Fininvest) ECLI:EU:C:2018:1023, para 44.

144 This was the constellation under C-6/99 Greenpeace France and Others EU:C:2000:148, para 57.

145 See for that discussion H.C.H. Hofmann, 'Composite decision making procedures in EU administrative law' in HCH Hofmann and A Türk (eds), Legal Challenges in EU Administrative Law (Cheltenham, Elgar Publishing, 2009) $136-67$.

146 C-644/17 Eurobolt ECLI:EU:C:2019:555, para 23.

147 C-644/17 Eurobolt ECLI:EU:C:2019:555, para 32.

148 C-219/17 Berlusconi (Fininvest) ECLI:EU:C:2018:1023, para 45.
} 
procedure do not so provide." ${ }^{\prime 149}$ Here the possibility of a preliminary reference under Article 267 TFEU is the means to ensure incidental control of the validity or interpretation of preparatory acts of EU institutions. ${ }^{150}$

A third constellation consists of composite procedures where several Member State authorities act together in one procedure in the scope of EU law. An example for this is the constellation discussed by the CJEU in Berlioz where it held that right to an effective judicial remedy under Article 47 CFR requires that one national administration, and subsequent judicial review of that national administration's decision, must be able to review another Member State administration's decision. In Berlioz, the CJEU established for the first time that the basis of that review will not be compliance with the other Member State's law, but its compliance with the requirements established by the EU directive establishing the possibility of a composite procedure linking various national administrations. ${ }^{151}$ This solution allows for a review by the courts and tribunals of one Member State of the actions of another Member State's administration against an EU standard, which constitutes a central innovation for ensuring effective remedies in an integrated but de-centrally administered EU. The standards of review established Berlioz are thus a further development of established case law of the CJEU, reconfirmed for example in Donnellan. There the Court held that in order to ensure respect for the rights laid down in Article 47 CFR, the addressee of a decision issued by a foreign authority to be enforced in another Member State must be notified of that decision so as to be "able to know and understand effectively and completely the meaning and scope of the action brought against him abroad." Otherwise, the individual would

\footnotetext{
149 C-219/17 Berlusconi (Fininvest) ECLI:EU:C:2018:1023, para 46.

${ }^{150}$ C-97/91 Oleoficio Borelli v Commission EU:C:1992:491, paras 9-13 as well as C-269/99 Carl Kühne and Others EU:C:2001:659, para 58; C-343/07 Bavaria and Bavaria Italia EU:C:2009:415, para 57.

151 C-682/15 Berlioz Investment Fund SA ECLI:EU:C:2017:373, paras 56 and 78-89. In para 89 the CJEU states that "Consequently, the answer to the third and fifth questions is that Article 1(1) and Article 5 of Directive 2011/16 must be interpreted as meaning that verification by the requested authority to which a request for information has been submitted by the requesting authority pursuant to that directive is not limited to the procedural regularity of that request but must enable the requested authority to satisfy itself that the information sought is not devoid of any foreseeable relevance having regard to the identity of the taxpayer concerned and that of any third party asked to provide the information, and to the requirements of the tax investigation concerned. Those provisions of Directive 2011/16 and Article 47 of the Charter must be interpreted as meaning that, in the context of an action brought by a relevant person against a penalty imposed on that person by the requested authority for non-compliance with an information order issued by that authority in response to a request for information sent by the requesting authority pursuant to Directive 2011/16, the national court not only has jurisdiction to vary the penalty imposed but also has jurisdiction to review the legality of that information order. As regards the condition of legality of that information order, which relates to the foreseeable relevance of the requested information, the courts' review is limited to verification that the requested information manifestly has no such relevance."
} 
not be able to effectively assert his rights in the Member State enforcing such foreign act. ${ }^{152}$ Berlioz goes a step further spelling out what Article 47 CFR requirements are specifically for such review of a foreign act in another Member State.

A fourth constellation of composite procedures consists of cases where a Member State act has an effect not only under national law but also under EU law. An example case for this constellation is addressed in Rimše evičs and ECB v Latvia, ${ }^{153}$ a case which addresses the fact that the Governors of national central banks of Member States are appointed to office and relieved from office under national law of the Member State but the Statute of the European System of Central Banks and the ECB sets certain conditions for their appointment and dismissal because the Governors of national central banks are equally the members of the European Central Bank's (ECB) Governing Council. Therefore, although it is for national Courts to decide on the legality of appointment or removal from office, where EU law establishes conditions for such acts, it is for the Member States courts to apply them and take them into account. ${ }^{154}$ Similarly, the CJEU has held in Rottman, in the context of a preliminary reference procedure (Article 267 TFEU) with respect to withdrawal of national citizenship having the effect of the loss of EU citizenship that Member States Courts must assess the matter under national law also in the context of EU law. ${ }^{155}$ The same result was reached in the action for annulment (Article 263 TFEU) in the case Le Pen where the General Court held that an action of an Member of the European Parliament (MEP) who in the context of criminal proceedings under national law inter alia was held to be incapable of holding office, has an effect on his status as MEP. However, it is for the national Courts to review the legality of such sanctions and to take into account the effect on EU law - in this case the effect on the status as MEP under EU law. ${ }^{156}$

152 C-34/17 Donnellan v The Revenue Commissioners ECLI:EU:C:2018:282, para 58; C-519/13 Alpha Bank Cyprus EU:C:2015:603, paras 31- 32

${ }^{153}$ See Order of the Vice-President of the Court in C-238/18 ECB v Latvia of 20 July 2018 ECLI:EU:C:2018:581 and Opinion of AG Kokott in C-202/18 Rimševičs and C-238/18 ECB v Latvia of 19 December 2018, ECLI:EU:C:2018:1030 (at the time of writing of this commentary the case is still pending).

${ }^{154}$ In the case C-238/18 ECB v Latvia, however, a specific provision in the Statues of the ESCB and ECB granting under Article 14.2. the CJEU powers to review (national) decisions or decisions of the ECB to relieve a Governor from office. "A decision to this effect may be referred to the Court of Justice by the Governor concerned or the Governing Council on grounds of infringement of these Treaties or of any rule of law relating to their application."

155 Case C-135/08 Rottmann v Freistaat Bayern, paras 41-55 with further references.

156 T-353/00 Jean-Marie Le Pen ECLI:EU:T:2003:112, para 91. 


\section{b. Specific Obligations in Disputes between Individuals - The 'horizontal' Relation}

The right to an effective judicial remedy is not limited to disputes between individuals and Member States or EU institutions and bodies. It is also applicable in view of the protection of rights arising from EU law in 'horizontal' disputes between individuals, either by means of what is known as 'indirect' effect or through 'direct horizontal effect'. The difference is that while direct horizontal effect creates rights and obligations directly between individuals in a dispute, indirect horizontal effect influences the interpretation of national law applicable in a dispute. ${ }^{157}$

(i) Indirect Horizontal Effect of the Right to Effective Remedies

Cases which have confirmed this indirect horizontal effect of the right to an effective judicial remedy have so far been decided by the Court especially with respect to rights arising from EU legislative acts - both in the form of directives or regulations. The policy area of nondiscrimination, consumer protection and health and safety provisions have been particularly productive. Case law can be categorised into various sets of obligations arising from Article 47 CFR for national courts.

Provide sufficient sanctions for non-compliance

Amongst the leading cases in this field are Von Colson ${ }^{158}$ and Dekker ${ }^{159}$ where the Court established that a Member State implementing a directive on equality between the sexes should do so in a way granting sanctions for violation of such rights which would dissuade violation and should guarantee real and effective judicial protection by inter alia having 'a real deterrent effect' on a person breaching the objectives of the directive. ${ }^{160}$ In the absence of a specific provision in the directive, the Member States were free to establish whichever sanctions regime-public or private, administrative or criminal—would be adequate. The Court has frequently referred to the

\footnotetext{
157 See e.g. C-231/96 Edis [1998] ECR I-4951, paras 36, 37.

158 Case 14/83 Van Colson [1984] ECR 1891.

159 C-177/88 Dekker v Stichting voor Jong Volwassenen (VJV) Plus [1990] ECR I-3941.

160 Case 14/83 Van Colson [1984] ECR 1891, para 23.
} 
original cases ${ }^{161}$ and from there developed the following principles that are applicable when a Union regulation does not specifically provide any penalty for an infringement, or refers for that purpose to national laws, regulations and administrative provisions:

"Article 4(3) [TEU] requires the Member States to take all measures necessary to guarantee the application and effectiveness of Community law. For that purpose, while the choice of penalties remains within their discretion, the Member States must ensure in particular that infringements of Community law are penalised under conditions, both procedural and substantive, which are analogous to those applicable to infringements of national law of a similar nature and importance and which, in any event, make the penalty effective, proportionate and dissuasive."162

Guidance on the application of these criteria was given in Pontin. There, the Court held that a Member State would violate the principle of equivalence if its legislation withheld a remedy generally existing under national law for the implementation of a Directive (in Pontin: damages and interest). Pontin had brought a case against dismissal whilst being pregnant. The applicable law of the Grand Duchy of Luxembourg provided only for the remedy of annulment of the dismissal but denied the claim for damages for wrongful dismissal that was otherwise available under Luxembourg law. The Court found this to be in violation of the principle of equivalence. ${ }^{163}$ Additionally, Member States, under the principle of effectiveness and the right to an effective judicial remedy, were bound to develop an effective remedy for violations of rights established in the Directive. ${ }^{164}$

Interpret jurisdictional rules in light of Article 47 CFR

Questions of jurisdiction of national courts in civil disputes will also be assessed in view of the right to an effective judicial remedy. ${ }^{165}$ In that context, Member State tribunals are specifically

161 See e.g. C-441/14 Dansk Industri EU:C:2016:278 (Grand Chamber) para. 30; C-407/14 Maria Auxiliadora Arjona Camacho v Securitas Seguridad España SA [2015], para. 31 on equal treatment in social policy; C-611/14 Canal Digital Danmark $A / S$, [2016] para. 30 in the field of unfair commercial contracts

162 C-186/98 Nunes et de Matos [1999] ECR I-4883, paras 9-11 with reference to Case 68/88 Commission v Greece [1989] ECR 2965, para 23.

163 C-63/08 Pontin [2009] ECR I-10467, paras 72-76.

164 C-63/08 Pontin [2009] ECR I-10467, paras 72-76.

165 C-327/10 Lindner [2011] ECR-11543 para 49. See also: G, EU:C:2012:142, paragraphs 47 and 48, C-112/13 A, [2014], para. 58. 
under the obligation to avoid situations of denial of justice in cases involving rights under EU law. ${ }^{166}$ As a consequence, national courts need to take into account, when deciding about jurisdiction, whether such a decision might lead to a situation where no judicial remedy exists since such an outcome would violate the right to an effective judicial review under EU law. The application of this approach by the CJEU, however, is not always consistent. ${ }^{167}$

Conduct ex officio review of EU law by national courts and tribunals

A related issue of denial of justice is generated by the question of whether national judges in ongoing procedures may be obliged to raise issues of EU law of their own motion (ex officio). This may be necessary to ensure that a remedy before a national tribunal for breach of EU law is effective. This question arises most frequently, but not exclusively, in disputes between individuals. Under the principle of equivalence, a Member State court will be obliged to apply EU law of its own motion, if it would be obliged to do so with regard to disputes involving national legal provisions. ${ }^{168}$ Whether the conditions of equivalence exist is assessed on a case-by-case basis ${ }^{169}$ and 'must be analysed by reference to the role of that provision in the procedure, its progress and its special features, viewed as a whole, before the various national instances. ${ }^{170}$ Where a national court is bound by the pleadings of the parties as to the type of relief and the remedies, but not as to the law applicable to the case, it might therefore be obliged to apply EU law on its own motion. ${ }^{171}$ It was established by the Court in Cofidis, ${ }^{172}$ and followed in subsequent cases $^{173}$ on the implementation of EU consumer protection Directives, that a national rule which in effect prohibits the national court from raising points of EU law of its own motion renders the

\footnotetext{
166 See also C-292/10 de Visser (Judgment of 15 March 2012), para 59.

167 See e.g. C-498/16 Schrems v Facebook ECLI:EU:C:2018:37 and AG Bobek in that same case discussing the various arguments matters to greater detail.

168 Joined Cases C-430/93 and C-431/93 V an Schijndel and Van Veen [1995] ECR 1-4705, para 17; C-126/97 Eco Swiss [1999] ECR I-3055, para 37; C-168/05 Mostaza Claro [2006] ECR I-10421, para 35. For further discussion see: Anthi Beka The Active Role of Courts in Consumer Litigation Intersentia (Amsterdam 2018).

169 See critically with further discussion e.g. G de Búrca, 'National procedural rules and remedies: The Changing Approach of the Court of Justice' in J Lonbay and A Biondi (eds), Remedies for Breach of EC Law (London, Wiley, 1997) chapter 4.

170 C-312/93 Peterbroeck [1995] ECR I-4599, para 14 with further references.

171 This will depend on whether the procedural provisions are designed to allow for the principles of iura novit curia (the court knows the law) or under the concept of da mibi facta, dabo tibi ius (give me the facts and I will give you the law).

172 Case 473/00 Cofidis SAv Fredout [2002] ECR I-10875.

${ }^{173}$ E.g. Case C-470/12 Pohotovost's. r. o. EU:C:2014:101, para 41; Case C-168/15 Tomášová EU:C:2016:602, para 28; Case C-377/14 Radlinger EU:C:2016:283, para 57.
} 
'application of the protection intended to be conferred on them by the Directive excessively difficult. ${ }^{174}$ It follows, the Court stated, that even in absence of specific pleadings by the consumer, "effective protection of the consumer may be attained only if the national court acknowledges that it has power to evaluate terms of this kind of its own motion". ${ }^{175}$ This obligation may further exist, where a national court reviews the enforceability of an arbitration award made in the context of a consumer contract. ${ }^{176}$ Accordingly, EU legislation protects these rights protected by Article 47 CFR, for example in the area of consumer protection. ${ }^{177}$ Given the importance of this approach, in Asturcom $v$ Nogueira, ${ }^{178}$ a case regarding the legality of an arbitration clause in a consumer contract, the CJEU held that, a national court confronted with such an arbitration clause is "obliged to assess of its own motion whether that clause is unfair" in the light of Article 6 of Directive $93 / 13$ on the protection of consumers. ${ }^{179}$

A limitation on the obligation on national tribunals to raise issues of EU law of their own motion can arise from the principle of res judicata and the prohibition on raising new arguments because of the expiry of procedural time limits. ${ }^{180}$ Van Schijndel $^{181}$ offers a good illustration of that approach. In that case the dispute concerned the compatibility of a contract with EU competition law. The CJEU held that a national cassation-level superior court (which generally only deals with

174 Case 473/00 Cofidis $S A v$ Fredout [2002] ECR I-10875, paras 36-38, requiring taking into 'account of each case's own factual and legal context as a whole, which cannot be applied mechanically in fields other than those in which they were made.'

175 Joined Cases C-240/98 to C-244/98 Océano Grupo and Others [2000] ECR I-4941, para 26; C-243/08 Pannon [2009] ECR I-4713, para 32; C-227/08 Martin Martín [2009] ECR I-11939, para 29; C-137/08 Pénzügyi Lízing [2010] ECR I10847, paras 48, 51-53; Order of the Court in C-76/10 Pohotovost [2010] ECR I-11557, paras 40-43; C-32/12 Soledad Duarte Hueros (Judgment of 3 October 2013). See also M Ebers, 'From Océano to Asturcom: Mandatory Consuer Law, Ex Officio Application of European Union Law and Res Judiciata' (2010) European Review of Private Law 823-46. See also C-472/11 Banif Plus Bank Zrt v Csaba Csipai, para 33.

176 C-168/05 Mostaza Claro, para 30; Order of the Court in C-76/10 Pohotovost, paras 53, 54.

${ }^{177}$ For example, Article 6(1) to Council Directive 93/13/EEC of 5 April 1993 on unfair terms in consumer contracts, where under arbitration clauses putting consumers at a disadvantage in the protection of their rights are not binding on consumers (OJ (1993) L 95, p. 29). Amongst the indicative list of unfair terms included in the Annex to Directive 93/13 (at paragraph 1(q)) are terms having the object or effect of "excluding or hindering the consumer's right to take legal action or exercise any other legal remedy, particularly by requiring the consumer to take disputes exclusively to arbitration not covered by legal provisions, unduly restricting the evidence available to him or imposing on him a burden of proof which, according to the applicable law, should lie with another party to the contract".

178 C-40/08 Asturcom v Nogueira [2009] ECR I-9579, para. 29.

179 See C-168/05 Mostaza Claro [2006] ECR I 10421, para. 38, and C-40/08 Asturcom v Nogueira [2009] ECR I-9579, paras. 53-54.

180 Such rules are applicable under the principle of equivalence if they 'are no less favourable than those governing similar domestic actions'. With further details, C-40/08 Asturcom Telecomunicaciones (n 155) [33]-[47]; Order of the Court in C76/10 Pohotovost, para 47.

181 Joined Cases C-430/93 and C-431/93 V an Schijndel and Van Veen [1995] ECR 1-4705. The case concerned a contractual dispute between two parties where one party raised the question of compatibility of a contract with EU competition law under what are now Arts 101 and 102 TFEU. 
pleas in law and not in fact) could refuse to hear new pleas on the compliance with EU law and would not be in breach of the right to effective judicial remedy if prior to reaching the cassationlevel (superior court) neither the parties nor the lower courts acting of their own motion had raised the relevant points of EU law. ${ }^{182}$ On the other hand, a Member State court, especially the first-level courts, which have the right to refer a preliminary question to the Court of Justice, cannot be barred by national procedural rules from accepting an argument by parties on the incompatibility of a national decision with EU law. Nor can they be precluded from raising the rights of the individual under EU law of their own motion. National procedural rules that have had the effect of doing so have, as in Peterbroeck, been held to be in violation of the principle of effective judicial protection and thus in violation of obligations under EU law. ${ }^{183}$ In general, today's CJEU's case law is highly differentiated. For example, in Finanmadrid"184 the CJEU reviewed "the progress and particular features of the Spanish order for payment proceedings" and found that under those procedural conditions, it was possible that decisions of non-judicial bodies could have the effect of res judicata. But "effective protection of the rights under that directive can be guaranteed only provided that the national procedural system allows the court, during the order for payment proceedings or the enforcement proceedings concerning an order for payment, to check of its own motion whether terms of the contract concerned are unfair." 185 Therefore, some independent court must be in charge to - if necessary - review ex officio the compliance with EU law of a decision.

What makes this case law on ex officio obligations to protect rights under EU law by Member States even more remarkable is the discrepancy, as in many matters relating to Article 47 CFR, between obligations imposed on Member State courts to the obligations the CJEU accepts for requirements of judicial review within the EU system. One example is the great reluctance of the CJEU to accept ex officio requirements of review, even of fundamental rights, of the CJ and the GC. On the other hand, national civil courts are quite readily submitted to the requirements in order to ensure effectiveness of EU law related rights. ${ }^{186}$

\footnotetext{
182 Joined Cases C-430/93 and C-431/93 V an Schijndel and Van Veen [1995] ECR 1-4705, paras 17-22.

183 C-312/93 Peterbroeck [1995] ECR I-4599, paras 14-21.

${ }^{184}$ C-49/14 Finanmadrid EFC SA, EU:C:2016:98, paras 45-47.

185 C-49/14 Finanmadrid EFC SA, EU:C:2016:98, para 46.

186 See further to this matter XXX in this volume.
} 


\section{Grant access to information}

Finally, it has been established that the right to effective enforcement of EU law includes a right for one private party to bring proceedings against another. The protection of business secrets and other confidential information must be undertaken by Member State courts in a way, which protects the rights for effective remedies. ${ }^{187}$ The case law is especially developed for breaches of EU competition law. ${ }^{188}$ Effectiveness of enforcement of competition law in principle precludes a provision of Member State law banning access to public competition proceedings files, absent the consent of the parties to those proceedings, when such access is sought to secure the effective judicial enforcement of Article 101 TFEU through a private law damages claim. The principle of effectiveness requires the national judge to weigh up all the relevant factors, including the protection of both business secrets and the traders who have cooperated with the public authorities in the course of a leniency programme, in deciding which documents can be released. Such action may be necessary to ensure that the right of individuals to obtain compensation from other individuals who breach EU competition law is not rendered nugatory through want of evidence. ${ }^{189}$ However, where access to documents held by EU institutions and bodies is a pre-condition for an effective private enforcement of EU law, the CJEU has shown to be very hesitant to interpret EU law, especially Regulation 1049/2001 with respect to requirements under Article 47 CFR. Here, the CJEU risks establishing double standards obliging Member State authorities to further reaching obligations in the light of effective enforcement of EU law, than it is willing to oblige EU institutions and bodies. Despite the telos of Regulation 1049/2001 requiring in its Article 1 "the fullest possible" and the fundamental procedural right of transparency (Article 42 CFR and Article 15 TFEU) as well as the necessity of access as an effective pre-condition to the exercise of the right to an effective judicial remedy, the CJEU has developed the opposing doctrine proclaiming

187 C-450/06 V arec EU:C:2008:91, paras 46-52.

188 Joined Cases C-295/04 and C-298/04 Manfredi and Others [2006] ECR I-6619, and C-453/99 Courage and Crehan [2001] ECR I-6279.

189 See C-536/11 Donau Chemie AG (Judgment of 6 June 2013) which built on principles established in C-360/09 Pfleiderer [2011] ECR I-5161. Note that while the Court of Justice made no reference to Art 47 of the Charter in Donan Chemie, and was rather confined to discussion of the right to an effective remedy as a general principle of law, Art 47 was referred to extensively in the Opinion of Advocate General Jääskinen of 7 February 2013 in that case. See more recently the Opinion of Advocate General Cruz Villalon of 3 October 2013 in C-365/12 P Commission v EnBW Energie BadenWirttenberg (Judgment pending). 
"a general presumption of confidentiality." 190 This presumption, albeit rebuttable, covers documents, which in may contain relevant public findings, which when disclosed upon request by an interested party, would allow for private enforcement of EU law.

Policy specific case law regarding obligations under Article 47 CFR

The right to an effective remedy, which in many senses is a meta right influencing the enforcement of rights and obligations arising from all areas of EU law, will necessarily have received specific interpretation in the context of various specific policy areas. In fact, the examples for the general approaches to the law cited above are all to be seen also in the context of the specific sets of facts arising from the specific setting of the individual policy area in which they arise. It is a formidable task for the CJEU to maintain a common approach and general line across policy areas and it is thus not surprising that this task is achieved in some areas with more success than in others.

Some examples from the case law of indirect horizontal effect of Article 47 CFR are illustrative of this. In the area of asylum and immigration policy, there is a line of case law interpreting to 'effective remedy' the right of asylum seekers challenging the return or transfer under the Dublin III Regulation only as provided specifically under its Art. 27(1) (and its scope as clarified in the Recital 19 of the Regulation which nonetheless itself refers to Art. 47 CFR) and hence only relying on secondary law without reference to Article 47 CFR itself. ${ }^{191}$ That however does not mean that in the field of asylum and immigration policy there is not also case law with a specific reference

\footnotetext{
190 C-365/12 P Commission v EnBW EU:C:2014:112 para 93 ; C-139/07 P Commission v Technische Glaswerke Ilmenau EU:C:2010:376; C-514/07 P C-528/07 P and C-532/07 P Sweden and Others $\mathrm{v}$ API and Commission, EU:C:2010:541, para 94; C-514/11 P and C-605/11 P LPN and Finland $\mathrm{v}$ Commission EU:C:2013:738, para 65; C-365/12 P Commission v EnBW EU:C:2014:112 para 93.

191 See e.g. C-155/15, Karim [Grand Chamber] EU:C:2016:410, para. 22; C-63/15, Ghezelbash, [Grand Chamber] EU:C:2016:409, paras 38-9, 47-53; C-670/16 Mengesteab [Grand Chamber] EU:C:2017:587, paras 42-3; 45-8; C-490/16 A.S. [Grand Chamber] EU:C:2017:585, paras 25-6; C-578/16 PPU C. K. and Others, EU:C:2017:127, paras 64-5, 75; C249/13 Boudjlida, EU:C:2014:2431, para. 58.
} 
to also Art. 47 CFR the right of effective remedy. ${ }^{192}$ In this field there has also been especially relevant developments linking the rights of the defence and the right to be heard. ${ }^{193}$

In the areas of civil procedure various contexts exist in which the CJEU has reviewed the provisions of Regulation 44/2001 on in the light of Article 47 CFR. ${ }^{194}$ Further there is case law regarding the interpretation of arbitral procedures in the light of Article $47 \mathrm{CFR}^{195}$ and the recognition and enforcement of foreign judgments of other Member States in accordance with Article 47 CFR. ${ }^{196}$

Finally, in criminal matters and police cooperation Article 47 CFR has been used in the context of the interpretation of obligations under the European Arrest Warrant, ${ }^{197}$ but there are also cases where the CJEU relies purely on secondary law when assessing judicial review of warrants despite arguments being made about Article 47 CFR. ${ }^{198}$ Also, cases exist where the Court refers to Article 6 ECHR, sometimes exclusively. ${ }^{199}$

Direct Horizontal Effect

It is important to recall that "even a clear, precise and unconditional provision of a directive seeking to confer rights on or impose obligations on individuals cannot of itself apply in a dispute exclusively between private persons". ${ }^{200}$ Therefore, the Court will examine whether fundamental rights protected

\footnotetext{
192 C-201/16 Shiri [Grand Chamber] EU:C:2017:805, para. 44 (on the objective of 'effective remedy' under the Regulation 'as in accordance with Art. 47 CFR'); C-348/16 Sacko, EU:C:2017:591, paras 28-31 (see especially para 31 according to which "It follows that the characteristics of the remedy provided for in Article 46 of Directive 2013/32 must be determined in a manner that is consistent with Article 47 of the Charter, which constitutes a reaffirmation of the principle of effective judicial protection"); C-239/14, Tall, EU:C:2015:824, para. 51; C-146/14 PPU Mahdi, EU:C:2014:1320, paras 50-2; C-604/12 N. EU:C:2014:302, para. 41.

${ }_{193}$ C-249/13 Boudjlida, EU:C:2014:2431, paras 41-2; C-166/13 Mukarubega, EU:C:2014:2336, paras 51-2

194 E.g. C-112/13, A, EU:C:2014:2195; paras 51, 56, 58, 60 ; C-327/10 Hypotećní banka EU:C:2011:745, paras 48, 49, C-292/10 G EU:C:2012:142, paras 47, 48.

195 C-536/13 Gazprom EU:C:2015:316 [Grand Chamber], paras 38-39.

196 C-559/14, Meroni, EU:C:2016:349, paras 42-3; C-24/16, Nintendo, EU:C:2017:724, paras 54, 56: the objective of ensuring EJP of the rights conferred by Community trademarks and designs under Reg. No 6/2002.

197 E.g. Joined Cases C-404/15 and C-659/15 PPU Pál Aranyosi and Robert Căldăraru v Generalstaatsanwaltschaft Bremen, EU:C:2016:198, paras 77-78.

${ }_{198}$ E.g. C-452/16 PPU Poltorak, EU:C:2016:858, para. 16; C-241/15 Bob-Dogi, EU:C:2016:385, paras 56-57

${ }^{199}$ E.g. C-571/17 PPU Ardic, EU:C:2017:1026, paras 73-74.

${ }^{200}$ Joined Cases C-569/16 and C-570/16 Bauer and Others ECLI:EU:C:2018:871 para 77; C-122/17 Smith EU:C:2018:631 para 43.
} 
under EU law may in and as of themselves have horizontal direct effect in disputes between parties inter se with the effect of precluding the application of national law contrary to such provisions. ${ }^{201}$ In Egenberger, a case on discrimination on the basis of religious affiliation, the Court pointed out that "Article 47 of the Charter on the right to an effective remedy is sufficient in itself and does not need to be made more specific by provisions of EU or national law to confer on individual s a right which they may rely on as such."202 Consequently, the Court held, that where national law cannot be interpreted in compliance with a directive, the national court may be "required to ensure within its jurisdiction the judicial protection for individuals" flowing from Article 47 CFR, if need, by dis-applying contrary national law. ${ }^{203}$ Under this case law, when protecting the right under Article 47 CFR a national Court will have to undertake in many cases a balancing exercise in compliance with the principle of proportionality in order to ensure that competing rights are fully complied with. However, this will need to be done, according to the CJEU, by "taking into consideration the balance struck between those interests by the EU legislature" in the relevant directive in case. ${ }^{204}$ Arguably, any EU directive will in and of itself need to be interpreted both by the national court and by the CJEU in compliance with ensuring the rights under Article 47 CFR. The CJEU in Bauer then finds that rights "guaranteed in the legal order of the European Union are applicable in all situations governed by EU law". ${ }^{205}$ That means that even where a right arises from a provision of the Charter of Fundamental rights and is implemented by a directive, such rights may have an effect between the parties and thus require protection by the national court. ${ }^{206}$ This is a central development which allows for horizontal effect of rights arising from the Charter or from general principles of EU law also in a horizontal relation, to be protected then by the right to an effective remedy.

National courts are obliged to dis-apply Member State law which would jeopardise or make ineffective a right arising from EU law. In Fuss $v$ Stadt Halle ${ }^{207}$ for example, the Court of Justice

\footnotetext{
201 Joined Cases C-569/16 and C-570/16 Bauer and Others ECLI:EU:C:2018:871 para 79.

202 C-414/16 Egenberger EU:C:2018:257 para 78.

203 C-414/16 Egenberger EU:C:2018:257 para 79.

${ }^{204}$ C-414/16 Egenberger EU:C:2018:257 para 81.

205 C-176/12 Association de médiation sociale EU:C:2014:2 para 42 with further references.

206 Joined Cases C-569/16 and C-570/16 Bauer and Others ECLI:EU:C:2018:871, para 53 stating that "since the national legislation at issue in the main proceedings is an implementation of Directive 2003/88, it follows that Article 31(2) of the Charter is intended to apply to the cases in the main proceedings" with reference, by analogy, to C-176/12 Association de médiation sociale EU:C:2014:2 para 43.

207 C-243/09 Fußv Stadt Halle [2010] ECR I-9849.
} 
held that the right to effective judicial review would be breached if a Member State court failed to sanction retaliatory measures which

"might deter workers who considered themselves the victims of a measure taken by their employer from pursuing their claims by judicial process and would consequently be liable seriously to jeopardise implementation of the aim pursued by the directive." 208

These general obligations are not specific to direct or indirect horizontal effect, as the CJEU makes clear in Bauer, a case of direct horizontal effect. ${ }^{209}$

\section{Limitations on the Right to an Effective Remedy Before a Court or Tribunal of the Member} State

Any right, including the right to an effective judicial remedy, "may be restricted, provided that the restrictions in fact correspond to objectives of general interest pursued by the measure in question and that they do not involve, with regard to the objectives pursued, a disproportionate and intolerable interference which infringes upon the very substance of the rights guaranteed." 210 The conditions of limitations are outlined in Article 52(1) CFR as requiring limitations to be based on law, respect the essence of the right and to comply with the principle of proportionality.

The test is therefore whether a proposed limitation touches upon the essence of the right or only limits a more peripheral element of scope of protection. Limitations touching the periphery may be permissible if they pursue a legitimate public policy objective and are proportionate. ${ }^{211}$ The latter requires that a measure limiting the right must not only be capable of achieving its public policy objective but where several appropriate measures exist which are more or less equally capable of achieving the objective, "recourse must be had to the least onerous" or better, the least limiting the right. ${ }^{212}$ The notion of 'least onerous' requires a clear definition of the rights in question, which need to be balanced with the public interest in achieving the regulatory objective.

\footnotetext{
208 C-243/09 Fußv Stadt Halle [2010] ECR I-9849, para 66, with reference, by analogy, to C-185/97 Coote [1998] ECR I5199 , paras 24 and 27.

209 Joined Cases C-569/16 and C-570/16 Bauer and Others ECLI:EU:C:2018:871, paras 91-92.

210 Joined Cases C-317/08 to C-320/08 Alassini (n 63), para 63 with reference to C-28/05 Doktor and Others [2006] ECR I5431, para 75 and the case law cited. See e.g. more recently C-418/11 Textdata Software GmbH (n 108). See also the judgment of the ECHR in Fogarty $v$ United Kingdom ECHR 2001-XI 33 (extracts).

211 See Art 52(1) CFR.

212 See for many eg C-343/09 Afton Chemical [2010] ECR I-7027, para 45.
} 
Finally, under the proportionality test, the overall balance between the objective and the means chosen must not be wholly unreasonable. ${ }^{213}$

By applying this framework, the requirement of 'effective' protection that arises from the principle of sincere cooperation (Art 4(3) TEU) is fitted into the overall conceptual framework for limitation of general principles and fundamental rights recognised by the EU legal order. ${ }^{214}$ The approach under EU law is very close to that taken by the European Court of Human Rights in establishing limitations to the right corresponding to Article 47 of the Charter in ECHR law; namely Articles 6 and 13 ECHR. ${ }^{215}$

a. Limitation required by law

The requirement that the limitation be established by law has rarely figured expressly in the case law regarding Article $47 \mathrm{CFR}$. Nonetheless, the increasingly more precise understanding of the CJEU of the working of fundamental rights under Article 52(1) CFR, has led to the Court in Liivimaa Lihaveis finding that where the lack of a remedy against a measure undertaken by Member States acting in the scope of EU law results from a 'manual' of an agency is not a limitation provided by law. ${ }^{216}$ Consequently, the CJEU holds that where a national decision "cannot be subject to an appeal, the programme manual does not comply with the principle of effective judicial protection laid down in the first paragraph of Article 47 of the Charter" 217 and

213 The most explicit and detailed discussion of proportionality to date seems to have been undertaken in C-283/11 Sky Österreich (Judgment of 22 January 2013), paras 52-67.

214 See as a restatement of the general approach eg Joined Cases C-317/08 to C-320/08 Alassini (n 63) [63]. With further discussion: J. Engström, 'The Principle of Effective Judicial Protection after the Lisbon Treaty' (2011) 4 Review of European Administrative Law 53-68, 61 et seq; S Prechal and R Widdershoven, 'Redefining the Relationship between "Rewe-effectiveness" and Effective Judicial Protection' (2012) Review of European Administrative Law 31-50.

215 In this sense the ECtHR in Bellet v France (n 37) recalls that in the Fayed $v$ United Kingdom judgment (n 37), 49-50 [65], citing Lithgow and Others v United Kingdom (1986) Series A no 102, 71 [194], and Ashingdane v United Kingdom (n 36), 24-25 [57], it was held that since establishing the principle of the right of access to a court in its judgment of 21 February 1975 in the case of Golder $v$ the United Kingdom ([n 32] 18 [36]) the Court has clarified its scope in the following terms: '(a) The right of access to the courts secured by Article 6 para. 1 is not absolute but may be subject to limitations; these are permitted by implication since the right of access by its very nature calls for regulation by the State, regulation which may vary in time and in place according to the needs and resources of the community and of individuals. (b) In laying down such regulation, the Contracting States enjoy a certain margin of appreciation, but the final decision as to observance of the Convention's requirements rests with the Court. It must be satisfied that the limitations applied do not restrict or reduce the access left to the individual in such a way or to such an extent that the very essence of the right is impaired. (c) Furthermore, a limitation will not be compatible with Article 6 para. 1 if it does not pursue a legitimate aim and if there is not a reasonable relationship of proportionality between the means employed and the aim sought to be achieved.'

${ }^{216}$ C-562/12 Liivimaa Lihaveis MTÜ v Seirekomitee EU:C:2014:2229, para 73.

${ }^{217}$ C-562/12 Liivimaa Lihaveis MTÜ v Seirekomitee EU:C:2014:2229, para 74. 
that "it is for the national courts to rule on the lawfulness of a disputed national measure and to regard an action brought for that purpose as admissible even if the domestic rules of procedure do not provide for this in such a case." 218

\section{b. Essence}

In Schrems I, the CJEU invalidated a Commission decision for violation of the very essence of the right to an effective judicial review. The CJEU stated that "legislation not providing for any possibility for an individual to pursue legal remedies in order to have access to personal data relating to him, or to obtain the rectification or erasure of such data, does not respect the essence of the fundamental right to effective judicial protection, as enshrined in Article 47 of the Charter." This was the first instance in which the CJEU has annulled an act for violation of the essence of Article 47 CFR but refers to a long history of case law under which the "very existence of effective judicial review designed to ensure compliance with provisions of EU law is inherent in the existence of the rule of law."219

Whether granting access to some form of remedies, but no access to courts that fulfil the basic requirements of independence, could limit the very essence of the right to an effective remedy will remain to be addressed by the CJEU. This matter may come to be discussed in the wake of the $L M$ case, where the CJEU stated repeatedly and clearly that

"the requirement of judicial independence forms part of the essence of the fundamental right to

a fair trial, a right which is of cardinal importance as a guarantee that all the rights which individuals derive from EU law will be protected and that the values common to the Member States set out in Article 2 TEU, in particular the value of the rule of law, will be safeguarded." 220 The CJEU continued to link this matter to the essence by stating that an individual could "suffer a breach of his fundamental right to an independent tribunal and, therefore, of the essence of his fundamental right to a fair trial, a right guaranteed by the second paragraph of Article 47 of the Charter."

\footnotetext{
218 C-562/12 Liivimaa Lihaveis MTÜ v Seirekomitee EU:C:2014:2229, para 75.

${ }^{219}$ Case 294/83 Les Verts v Parliament EU:C:1986:166, para 23; Case 222/84 Johnston EU:C:1986:206, paras 18, 19; Case 222/86 Heylens and Others EU:C:1987:442, para 14; C-428/06 to C-434/06 UGT-Rioja and Others EU:C:2008:488, para 80. ${ }^{220}$ C-216/18 PPU LM ECLI:EU:C:2018:586 paras 48 and 51.
} 


\section{c. Proportionate limitations of the Right to an Effective Judicial Remedy}

The Court of Justice has held that it is not a disproportionate limitation if Member State procedural rules require satisfaction of additional steps before access to a Court can be granted. Such legitimate steps include, for example, compliance of national sanctions and procedural rules under which Member State courts operate to provide an effective remedy. Statutory limits defining limitation periods for bringing actions before national courts thus do not necessarily run contrary to Union law, ${ }^{221}$ as long as they are not "less favourable than those relating to similar domestic claims (principle of equivalence) and must not be so framed as to make it virtually impossible or excessively difficult to obtain reparation (principle of effectiveness)." 222 These concepts are today understood in the context of limitations of the right to an effective remedy under Article 47 CFR. ${ }^{223}$ In Peterbroeck, ${ }^{224}$ the Court of Justice accepted, in principle, the application of time limits and statutory limitations barring an applicant from bringing a case or requesting a remedy in an on-going procedure as long as their application did not make access to courts ineffective in reality. The Pontin case has established that "a fifteen-day limitation period applicable to an action for a declaration of nullity and for reinstatement ... does not appear to meet" the conditions required by this principle. ${ }^{225}$ The same holds true in principle for statutory limits to initiate complaint proceedings before administrative bodies when these are a pre-condition for obtaining standing before a court. Time-bar rules of this kind are, in principle, capable of complying with EU law, but they may fail to satisfy the principle of effectiveness, due to specific circumstances of a case. ${ }^{226}$

\footnotetext{
221 A Ward, Judicial Review and the Rights of Private Parties in EU Law, 2nd edn (Oxford, Oxford University Press, 2007) 11327; C-30/02 Recheio-Cash \& Carry (n 91) [21]-[22], [26].

222 C-261/95 Palmisani [1997] ECR I-4025 C-261/95, para 27.

${ }^{223}$ See also Sacha Prechal, The Court of Justice and Effective Judicial Protection: what has the Charter changed? in: C. Paulussen, T. Takács, V. Lazić, B. Van Rompuy (eds.) Fundamental Rights in European and International Law (The Hague, TMC Asser Press 2018) 143-157 at 150.

224 C-312/93 Peterbroeck [1995] ECR I-4599, para 15.

225 C-63/08 Pontin [2009] ECR I-10467, paras 62 and 69. Compare however C-69/10 Dioufv Ministre du Travail, de l'Emploi et de l'Immigration ECLI:EU:C:2011:524, para 67: "a 15-day time limit for bringing an action does not seem, generally, to be insufficient in practical terms to prepare and bring effective action and appears reasonable and proportionate in relation to the rights and interests involved." See similarly C-418/11 Texdata Software GmbH (Judgment of 26 September 2013), paras 80 and 81. Compare also C-339/12 RX II Oscar Orlando Arango Jaramillo (Judgment of 28 February 2013), in which no time-limit had been set to challenge measures taken by the European Investment Bank.

226 With regard to public procurement procedures e.g. C-241/06 Lämmerzabl GmbH v Freie Hansestadt Bremen [2007] ECR I-8415, para 57. In such a case a national time-bar rule may not be applied in such a way that a tenderer is refused access to review concerning the choice of procedure for awarding a public contract.
} 
Other legitimate steps limiting access to a judge recognised in EU law include, for example, 'making the admissibility of legal proceedings concerning electronic communications services conditional upon the implementation of a mandatory attempt at settlement. ${ }^{227}$ Similarly, the case of Evans is an instructive example of the operation of the general limitations principle in the context of the right to an effective judicial remedy. ${ }^{228}$ In that case, the United Kingdom had implemented a directive on compensation of victims' damage or injury caused by unidentified or insufficiently insured vehicles in traffic accidents by delegating the assessment of damages to an agency. Appeal against agency decisions were to be made to an independent arbitrator whose decisions were, on limited grounds only, subject to review by a national Court. The Court of Justice was satisfied that those arrangements did not "render it practically impossible or excessively difficult to exercise the right to compensation." 229 The difference to Wilson, is most likely the independence of the awards arbitrator by comparison to an internal review by a decision-making body, the former deemed insufficient by the Court. ${ }^{230}$

A further limitation of the right to an effective judicial remedy has been recognised in the context of competition law. The Court of justice has acknowledged that the right of access to a tribunal can be misused by dominant market participants as a strategy to harass competitors. Restricting such harassment might not only be an option but an obligation, in order to enforce the prohibition of misuse of a dominant position under Article 102 TFEU. The General Court, in Promedia, held that, since the right to an effective judicial remedy was a fundamental right, 'it is only in wholly exceptional circumstances that the fact that legal proceedings are brought' 'could be viewed as constituting an abuse of a dominant position within the meaning of Article 86 [now Art 102] of the Treaty. ${ }^{231}$

Member States need 'to protect the essential interests of its security and the guarantee of the procedural rights enjoyed by Union citizens ${ }^{232}$ when deciding whether a restriction on the right to an effective remedy is proportionate. Thus restrictions 'must be counterbalanced by appropriate

\footnotetext{
7 Joined Cases C-317/08 to C-320/08 Alassini [2010] ECR I-2213, para 62.

C-63/01 Evans [2003] ECR I-14447.

C-63/01 Evans [2003] ECR I-14447, para 54.

C-63/01 Evans [2003] ECR I-14447, para 54.

T-111/96 ITT Promedia [1998] ECR II-2937, para 60; Case T-105/95 WWF UK [1997] ECR II-313, para 56.

232 AG Bot Opinion of 12 September 2012 in C-300/11 ZZ, para 3.
} 
procedural mechanisms capable of guaranteeing a satisfactory degree of fairness in the procedure. ${ }^{233}$

Finally, individual parties may limit in certain circumstances their own right to an effective remedy under Article 47 CFR. For example, in relation to commercial arbitration, the CJEU has held "that the requirements of efficient arbitration proceedings justify the review of arbitral awards by the courts of the Member States being limited in scope, provided that the fundamental provisions of EU law can be examined in the course of that review and, if necessary, be the subject of a reference to the Court for a preliminary ruling." 234

\section{Access to Judicial Review versus the Question of Degree of Review}

To date the CJEU case law on the right to an effective remedy, despite stating the need for de jure and de facto effective remedies mostly focusses on matters of admissibility and accessibility to a particular type of remedy. ${ }^{235}$ The question of what kind of degree of review, or with other words, the intensity of review will be offered by a court or tribunal, once access has been granted, has been discussed mostly in the context of the necessity of national courts offering specific forms of redress. Examples are matters of interim relief, ${ }^{236}$ declaratory relief in various contexts, ${ }^{237}$ or $e x$ officio recourse to matters of EU law. ${ }^{238}$ Accordingly, the CJEU in Wilson held that review by an independent tribunal that was limited to questions of law and did not extend to a review of the facts, was insufficient. ${ }^{239}$

But one of the core difficulties and differences under EU law is to establish the relation between judicial self-restraint in the context of legislative or executive discretion, on one hand, and a welldeveloped review under criteria of proportionality and compliance with legal requirements on the other. Statements of the CJEU that Member State courts were obliged to undertake "thorough review", for example, have not been further elaborated as to which kind of review would comply

\footnotetext{
233 AG Bot Opinion of 12 September 2012 in C-300/11 ZZ, para 83.

${ }^{234}$ C-284/16 Achmea ECLI:EU:C:2018:158 (Grand Chamber), para 54 with reference to C-126/97 Eco Swiss EU:C:1999:269, paras 35, 36 and 40; C-168/05 Mostaza Claro EU:C:2006:675, paras 34-39.

235 See also Brunessen Bertrand, Jean Siinelli, 'Le Principe du droit au juges et à une protection juridictionelle effective', in: Jean-Bernard Auby, Jacqueline Dutheil de la Rochère (eds.) Traité de droit Administratif Européen 2ième ed. (Bruylandt, Bruxelles 2014) 567-593 at 580.

236 E.g. C-213/89 Factortame and Others [1990] ECR I-2433.

${ }^{237}$ C-263/02 P Jégo-Quéré ECLI:EU:C:2004:210; C-362/14 Schrems v DPC ECLI:EU:C:2015:650, para 65.

${ }^{238}$ E.g. C-40/08 Asturcom v Nogueira [2009] ECR I-9579, paras. 29 and 51-52.

239 C-506/04 Wilson [2006] ECR I-8613, para 62.
} 
with that standard, other than the Wilson-requirement that a court should be able to review law and fact of a case. ${ }^{240}$ In that vein, recently the CJEU has been asked to address preliminary reference from Hungary in which the referring Court puts forward the argument that there is a doubt about the relation between Court review under Article 47 CFR and that of administrations. ${ }^{241}$ It asks whether under Article $47 \mathrm{CFR}$, courts have the power to amend administrative decisions themselves, instead simply reviewing the legality of such decision and referring the matter back. This very question is, in fact, addressed quite differently in various EU Member States as well as between various policy areas as to the distribution between the role of the court or tribunal and the other branches of public powers. In this respect, under Article 52(3) CFR the case law of the ECtHR, which has established important standards regarding the scale of judicial review required under Article $6 \mathrm{ECHR},{ }^{242}$ is to be taken into account for clarification of minimum standards of the degree of review required.

\footnotetext{
240 See e.g. C-69/10 Dioufv Ministre du Travail, de l'Emploi et de l'Immigration ECLI:EU:C:2011:524, paras 56, 57 with reference to C-506/04 Wilson [2006] ECR I-8613, paras 60-62.

241 Pending C-556/17 Alekszij Torubarov v Bevándorlási és Menekültügyi Hivatal - Request for a preliminary ruling from the Pécsi Közigazgatási és Munkaügyi Bíróság (Hungary) lodged on 22 September 2017. The question is: "Is Article 46(3) of Directive 2013/32/EU 1 of the European Parliament and of the Council of 26 June 2013 on common procedures for granting and withdrawing international protection, in conjunction with Article 47 of the Charter of Fundamental Rights of the European Union, to be interpreted as meaning that the Hungarian courts have the power to amend administrative decisions of the competent asylum authority refusing international protection, and also to grant such protection?" 242 See for example Menarini v Italy App no 43509/08 (27 September 2011); Jusssila v Finland Case 2006-XIII (23 November 2006); Hatton and Others v United Kingdom App no 36022/97 (8 July 2003) paras 141-142; Case 34619/97 Janosevic v Sweden (21 May 2003); Société Stenuit v France No 73053/01 (27 February 1992); Engel and Others v Netherlands (Series A, No 232-A) of 8 June 1976.
} 